\title{
Vascular Anomalies: From Genetics toward Models for Therapeutic Trials
}

\author{
Melanie Uebelhoer ${ }^{1}$, Laurence M. Boon ${ }^{1,2}$, and Miikka Vikkula ${ }^{1}$ \\ ${ }^{1}$ Laboratory of Human Molecular Genetics, de Duve Institute, Université Catholique de Louvain, \\ B-1200 Brussels, Belgium \\ ${ }^{2}$ Center for Vascular Anomalies, Cliniques Universitaires St Luc, B-1200 Brussels, Belgium \\ Correspondence: miikka.vikkula@uclouvain.be
}

\begin{abstract}
Vascular anomalies are localized abnormalities that occur during vascular development. Several causative genes have been identified not only for inherited but also for some sporadic forms, and the molecular pathways involved are becoming understood. This gives us the opportunity to generate animals carrying the causative genetic defects, which we hope model the phenotype seen in human patients. These models would enable us not only to test known antiangiogenic drugs, but also to develop novel approaches for treatment, directly targeting the mutated protein or molecules implicated in the pathophysiological signaling pathways.
\end{abstract}

$V$ ascular anomalies are localized lesions of blood vessels that occur because of defects during angiogenesis. On the basis of biological and clinical criteria, they can be divided into vascular tumors and vascular malformations (Mulliken and Glowacki 1982). Whereas hemangiomas account for the majority of vascular tumors, vascular malformations comprise venous, capillary, arterial, lymphatic, and combined malformations (Boon and Vikkula 2008). These lesions can either cause limited aesthetic harm or be of major medical concern because of painfulness, bleeding, and destruction of tissues leading to diminished function. Although small lesions can often be well treated, therapies are limited for complicated lesions, necessitating the development of novel approaches. To this end, known antiangiogenic drugs are being tested for some vascular anomalies, and mouse models are being generated on the basis of etiopathogenic causes (summarized in Table 1).

\section{HEMANGIOMA}

Infantile hemangiomas (IHs) are the most common benign tumors of infancy, appearing in $\sim 10 \%$ of neonates of European origin. IHs affect females more frequently than males, at a ratio of 3:1 (Boscolo and Bischoff 2009). They are mostly located on the head and neck $(60 \%)$ and mostly involve the skin and subcutaneous tissue (Fig. 1A) (Boscolo and Bischoff 2009).

Infantile hemangiomas are characterized by a proliferating phase with rapid increase in

Editors: Michael Klagsbrun and Patricia D'Amore

Additional Perspectives on Angiogenesis available at www.perspectivesinmedicine.org

Copyright (C) 2012 Cold Spring Harbor Laboratory Press; all rights reserved; doi: 10.1101/cshperspect.a009688

Cite this article as Cold Spring Harb Perspect Med 2012;2:a009688 


\section{$\$_{\mathrm{CSH}}^{\infty}$ Cold Spring Harbor Perspectives in Medicine

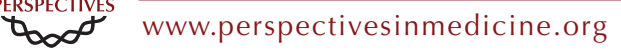

Table 1. Summary of identified genetic bases of vascular malformations/syndromes with a major vascular malformation component

\begin{tabular}{|c|c|c|c|c|c|c|}
\hline Malformation & Locus & Gene & Functions/pathways & Interactors/effectors/targets & Animal models & Molecules \\
\hline Hemangioma & $5 p 31-33$ & $\begin{array}{l}\text { VEGFR3? } \\
\text { PDGFR- } \beta \text { ? } \\
\text { FLT4? } \\
\text { VEGFR2 } \\
\text { TEM8 }\end{array}$ & $\begin{array}{l}\text { VEGF receptor; EC } \\
\text { proliferation, survival, } \\
\text { migration; tubular } \\
\text { morphogenesis; sprouting } \\
\text { integrin-like receptor }\end{array}$ & $\begin{array}{l}\beta \text {-integrin; NFAT; VEGFR1; } \\
\text { VEGFA; ERK1/2 }\end{array}$ & $\begin{array}{l}\text { Hemangioma stem } \\
\text { cell-implanted } \\
\text { mice }\end{array}$ & $\begin{array}{l}\text { Propanolol } \\
\text { ( } \beta \text {-blocker); } \\
\text { acebutolol } \\
\text { ( } \beta \text {-blocker }) ; \\
\text { corticosteroids }\end{array}$ \\
\hline \multicolumn{7}{|l|}{ Venous anomalies } \\
\hline $\begin{array}{l}\text { Venous malformation } \\
\text { (VM) }\end{array}$ & $9 p 21$ & TIE2/TEK & $\begin{array}{l}\text { Tyrosine kinase receptor; EC } \\
\text { migration, proliferation, } \\
\text { survival; SMC recruitment; } \\
\text { vascular sprouting, } \\
\text { maturation, stability; } \\
\text { hematopoietic quiescence }\end{array}$ & $\begin{array}{l}\text { Ang1, 2, and } 4 \text { (ligands); } \\
\text { } 5 \beta 1 \text { integrin; TIE1; } \\
\text { PI3K/Akt; survivin; FAK; } \\
\text { RhoA; Rac1; eNOS; Dok-R; } \\
\text { Grb2,7,14; Ras; ERK1/2; } \\
\text { p38MAPK; STATs; } \\
\text { VE-PTP; apelin; HGF }\end{array}$ & Tie $2^{-/-}$ & TIE2 inhibitors? \\
\hline $\begin{array}{l}\text { Glomuvenous } \\
\text { malformation (GVM) }\end{array}$ & $1 p 21-22$ & GLMN & $\begin{array}{l}\text { SMC differentiation; protein } \\
\text { synthesis/degradation; } \\
\text { TGF- } \beta \text {, HGF pathways }\end{array}$ & $\begin{array}{l}\text { FKBP12; c-Met; p70S6K; } \\
\text { Cul7 }\end{array}$ & glomulin knockdown & mTOR inhibitors? \\
\hline \multicolumn{7}{|l|}{ Capillary anomalies } \\
\hline $\begin{array}{l}\text { Capillary malformation- } \\
\text { arteriovenous } \\
\text { malformation } \\
(\mathrm{CM}-\mathrm{AVM})\end{array}$ & $5 q 13-22$ & RASA1 & $\begin{array}{l}\text { Ras/MAPK inhibition; cell } \\
\text { motility, survival }\end{array}$ & $\begin{array}{l}\text { PDGFß; EGFR; FGFR; } \\
\text { EphB2,B4; AKT; } \\
\text { p190RhoGAP; FAK }\end{array}$ & Mosaic Rasa1 ${ }^{-/-}$ & $\begin{array}{l}\text { mTOR inhibitors? } \\
\text { Ras inhibitors? }\end{array}$ \\
\hline \multirow[t]{3}{*}{$\begin{array}{l}\text { Cerebral cavernous } \\
\text { malformation }(\mathrm{CCM})\end{array}$} & $7 q 11-22$ & KRIT1 & $\begin{array}{l}\text { Adaptor protein; integrin- } \beta 1 \\
\text { pathway; arterial } \\
\text { specification; cell adhesion, } \\
\text { migration }\end{array}$ & $\begin{array}{l}\text { ICAP-1 } \alpha \text {; microtubules; } \\
\text { Rap1; SNX17; CCM2 and } \\
\text { 3; NOTCH; ERK1/2; } \\
\text { PI3K/Akt HEG1 }\end{array}$ & $\begin{array}{l}C c m 1^{+/-} \operatorname{Trp} 53^{-/-} \\
\quad C c m 1^{+/-}\end{array}$ & $\begin{array}{l}\text { Sorafenib } \\
\text { (antiangiogenic } \\
\text { drug); simvastatin } \\
\text { (RHOA inhibitor); }\end{array}$ \\
\hline & $7 p 13$ & Malcavernin & $\begin{array}{l}\text { Adaptor protein; osmosensing; } \\
\text { overlap with above }\end{array}$ & $\begin{array}{l}\text { MEKK3; Rac1; CCM1 and 3; } \\
\text { RHOA; SMURF1 }\end{array}$ & $\begin{array}{l}\text { Tie2-Cre; } \mathrm{Ccm} 2^{-/-} \\
\quad \text { Ccm } 2^{+/-}\end{array}$ & $\begin{array}{l}\text { Y-27632 (ROCK } \\
\text { inhibitor) }\end{array}$ \\
\hline & $3 q 26.1$ & PDCD10 & Apoptosis? overlap with above & CCM1 and 2 & & $\begin{array}{l}\text { Fasudil (ROCK } \\
\text { inhibitor) }\end{array}$ \\
\hline
\end{tabular}




\section{Arterial/combined malformations}

\section{Hereditary hemorrhagic 9q33-34 ENG}

telangiectasia (HHT)

or Rendu-Osler-Weber

(ROW)

\section{2q11-14 ALK1}

Juvenile polyposis HHT $18 q 21.1$ SMAD4 (JPHT)

\section{Lymphatic anomalies}

Lymphatic malformation -

$$
\text { (LM) }
$$

Primary congenital LE 5q35.3 VEGFR3/

(Nonne-Milroy

disease)

Hydrops

LE-distichiasis (LD) $\quad 16 q 24.3 \quad$ FOXC2
hydrops

Hypotrichosis-LEtelangiectasia (HLT)

hydrops
Type III TGF- $\beta$ receptor; TGF- $\beta$ TGF- $\beta$; activins; BMPs family signal modulation; EC hypoxia-survival, migration, proliferation; vascular organization; monocytemacrophage transition; myogenic differentiation; erythroid development

Type I TGF- $\beta$ receptor; TGF- $\beta$ family (-independent) signal transduction; EC migration, proliferation

(ligands); TGF- $\beta$ RII; TGF- $\beta$ RIs (ALK1, 5); MAPK; $\beta$-arrestin 2;

Tctex $2 \mathrm{~b} ;$ Smad 1

$$
\begin{gathered}
\text { Eng }^{+/-} ; \text {Eng-iKO }^{e} \\
(\text { EC-specific } \\
\text { Eng } \left.^{-1-}\right)
\end{gathered}
$$

tracellular mediator; TGF- $\beta$ signaling

$$
\begin{aligned}
& \text { TGF- } \beta \text {; activins; BMPs } \\
& \text { (ligands); TGF- } \beta \text { RII; } \\
& \text { endoglin; Smad1, -5, -8; } \\
& \text { Id1 } \\
& \text { TGF- } \beta \text {; activins; Smad 2, 3; } \\
& \text { BMPs (ligands); SNIP1; } \\
& \text { Sp1; MSG1; } \beta \text {-catenin; } \\
& \beta \text {-tubulin, etc. }
\end{aligned}
$$

Tyrosine kinase receptor; EC proliferation, migration, survival; angiogenic sprouting, network formation; lymph-vessel formation

Transcription factor; arterial cell $\mathrm{Smad} 3 ; \mathrm{Su}(\mathrm{H})$; inhibition of $\mathrm{Foxc2}^{+/-}$

Acvrl $^{+/-}$; $\operatorname{L1cre}(+) ; A l k 1^{3 l o x P}$ 3 loxP $(\mathrm{EC}$-specific $\left.A l k^{-/-}\right)$

Smad $4^{+/-}$(polyps, tumors)

mTOR inhibitors?

\section{VEGF-C, D (ligands); \\ VEGFR2; Shc; Grb2; \\ PLCg/PKC; p42/}
Vegfr3 $3^{-/-}$
overexpressing
Vegfr3; Chy

ligand-based
Tacrolimus;

raloxifene (SERM);

Avastin (VEGF-

inhibitor);

thalidomide specification; angiogenesis, vascular remodeling; VEGF, Notch pathways; insulin,

TGF- $\beta$ signaling

Transcription factor

arteriovenous specification;

lymphatic EC differentiation
PDGFß secretion;

induction of Ang2,

integrin $\beta 3$, fibronectin,

CXCR4, Dll4, Hey2

MEF2C; induction of Prox1, Ragged

VCAM-1 
M. Uebelhoer et al.
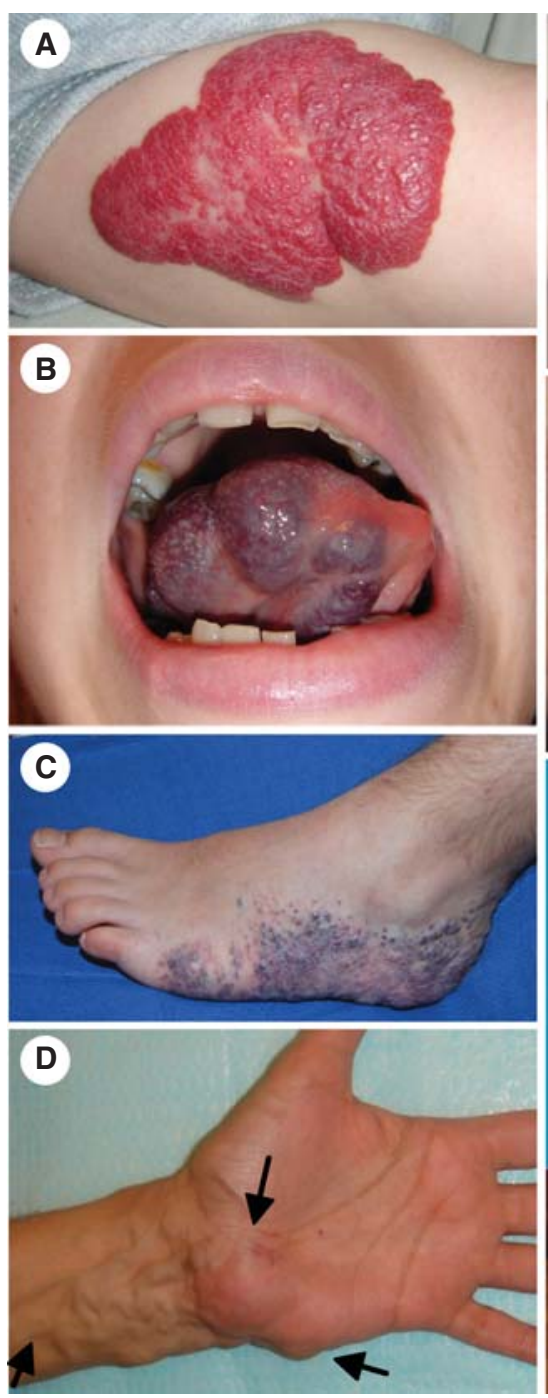
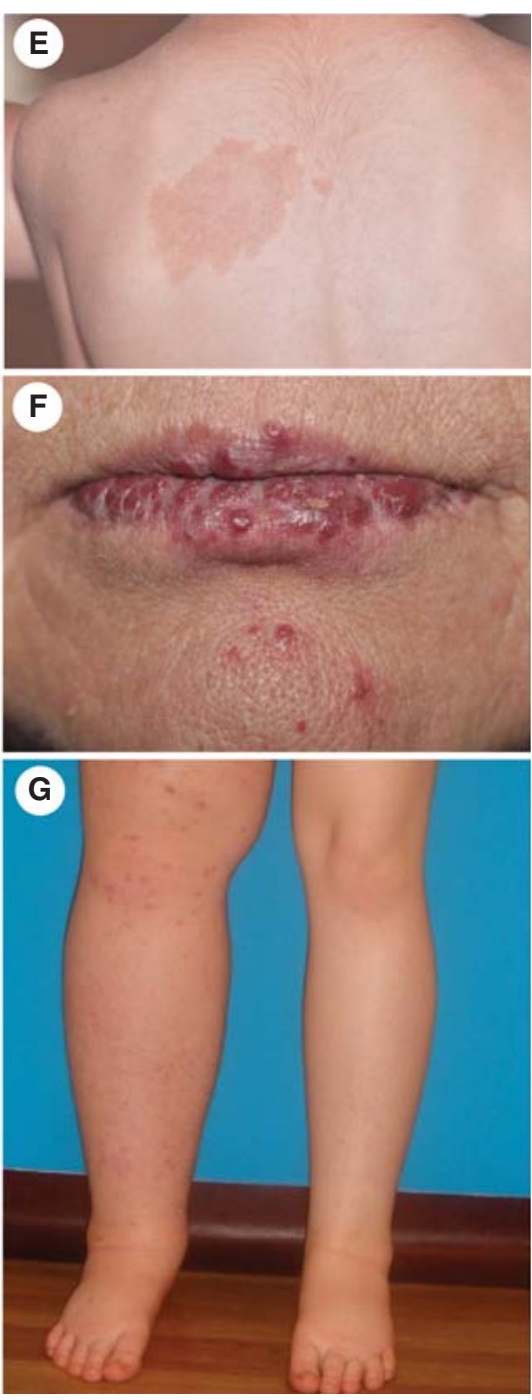

Figure 1. Selected vascular anomalies. (A) Hemangioma on forearm. (B) Venous malformation (VM) on tongue. $(C)$ Glomuvenous malformation (GVM) on foot. (D) Arteriovenous malformation (AVM) on hand. (E) Capillary malformation (CM) of capillary malformation-arteriovenous malformation (CM-AVM) on back. (F) Hereditary hemorrhagic telangiectasias (HHT) on lips. $(G)$ Primary lymphedema on right leg.

tumor size until the age of 6-12 mo, followed by an involuting phase, during which IHs spontaneously regress and eventually disappear by the age of 5-10 yr (Mulliken and Glowacki 1982; Boscolo and Bischoff 2009). Depending on the size and location, IHs can lead to tissue and organ damage and even become lifethreatening. The proliferating phase of $\mathrm{IH}$ is histologically characterized by the presence of small vascular channels composed of clonal endothelial cell (EC) clusters mixed with pericytes, dendritic cells, and an elevated number of mast cells. Undifferentiated endothelial cells expressing the human stem cell marker CD133 are also present. The theory of nascent endothelium is supported by the expression of angiogenic factors and receptors: vascular endothelial growth factor A (VEGF-A), VEGFreceptors VEGFR-1 and VEGFR-2, basic fibroblast growth factor (bFGF), TIE2, and 
angiopoietin-2 (ANGPT2) (Boscolo and Bischoff 2009). The involuting phase, on the other hand, is characterized by more prominent vascular channels covered by flat, normalappearing ECs in a fibrous-fatty matrix, devoid of clusters of immature cells (Mulliken and Glowacki 1982; Boscolo and Bischoff 2009).

The molecular basis of the usually sporadically occurring IHs is unknown, but rare familial cases and epidemiological studies support the idea of a genetic influence (Chiller et al. 2002; Haggstrom et al. 2007). Autosomaldominant inheritance in five families allowed the identification of a possible locus on $5 q 31$ 33 containing three candidate genes (Blei et al. 1998; Walter et al. 1999).

Germline nucleotide substitutions in VEGFR2/KDR and the integrin-like receptor TEM8/ANTXR1 are enriched in affected individuals (Jinnin et al. 2008). These mutant receptors can sequester $\beta$-integrin in a complex that negatively regulates $\beta$-integrin activity and NFAT transcriptional function, resulting in reduced expression of VEGFR1. A low level of VEGFR1, in turn, translates into lower sequestering of VEGF-A, which thus is able to bind to and activate VEGFR2 and its downstream target ERK (Jinnin et al. 2008). Addition of soluble VEGFR1 or silencing of VEGFR2 in hemangioma ECs (hemECs) reduces VEGFR2 signaling and the high proliferative activity of ECs (Jinnin et al. 2008). This fits with the consistent detection of increased VEGF-A levels in hemangiomas, hemECs (Takahashi et al. 1994; Chang et al. 1999; Jinnin et al. 2008), and in serum of patients with proliferating hemangiomas (Zhang et al. 2005).

Current treatments of $\mathrm{IH}$ are based on the $\beta$-adrenergic receptor antagonists propranolol or acebutolol, as well as corticosteroids. $\beta$ blockers might act through down-regulation of angiogenic factors, such as VEGF and bFGF, and up-regulation of apoptosis of capillary ECs (Leaute-Labreze et al. 2008). They may also inhibit the angiogenic and extracellular matrix degrading molecule MMP9 (Annabi et al. 2009). Bradycardia, hypotension, asthma, and hypoglycemia are possible side effects (Holland et al. 2010). Corticosteroids, on the other hand, bear the risk of Cushingoid facies, growth disturbance, immune system dysfunction, gastric ulcer, and personality changes; and $30 \%$ of patients do not respond (Boon et al. 1999). The use of agents including chemotherapeutic interferon- $\alpha$, vincristine, and cyclophosphamide is restricted to IHs that do not respond to conventional therapies because of severe side effects and toxicity (Greinwald et al. 1999; Enjolras et al. 2004; Vlahovic et al. 2009).

Loss-of-function murine models of Vegf-A, Vegfr1, and Vegfr2 are embryonically lethal. Vegf- $A^{+/-}$and Vegfr1 $1^{-/-}$mice die at embryonic day 10.5 (E10.5) or E8.5, respectively, from abnormal differentiation of blood islands and disorganized vasculature (Fong et al. 1995; Carmeliet et al. 1996). Vegfr2 ${ }^{-/-}$mice die at E8.5-E9.5 with absent yolk sac blood islands due to blocked migration of angioblasts (Shalaby et al. 1995). To better mimic IHs, a mouse model was generated using hemangioma-derived stem cells implanted into immuno-deficient mice. This results in formation of hemangioma-like lesions that involute to fatty tissue (Khan et al. 2008), mimicking their evolution. This elegant model may help identify molecular mechanisms underlying $\mathrm{IH}$ and to develop and test new therapies.

\section{VENOUS ANOMALIES}

With an incidence estimated at 1/5000-1/ 10,000 , venous anomalies are among the most frequent vascular anomalies referred to specialized centers because of morbidity (Boon et al. 1994). The two major subclasses are venous malformation (VM; MIM 600195), accounting for $\sim 95 \%$ of venous anomalies, and glomuvenous malformation (GVM; MIM 138000), accounting for the majority of the remaining $5 \%$. Certain syndromes also include venous anomalies, such as Blue rubber bleb nevus syndrome (BRBN; MIM 112200), Klippel-Trénaunay syndrome (KT; MIM 149000), and Maffucci syndrome (MS; MIM 166000). The etiopathogenic mechanisms underlying these sporadically occurring syndromes remain unknown. 
M. Uebelhoer et al.

\section{Venous Malformation}

Predominantly sporadic (98\%), VM can rarely be inherited (named mucocutaneous venous malformation; VMCM) (Boon et al. 1994). VMs are soft, compressible, light-to-dark blue lesions that mainly occur on skin and mucosa (Fig. 1B) and often infiltrate underlying tissues, muscles, and joints (Dompmartin et al. 2010). They can be painful, but not on palpation (Boon et al. 2004). Whereas VMCM patients usually present small, multifocal lesions, those in sporadic patients are mostly large and unifo$\mathrm{cal}$ and infiltrate more often into underlying tissues (Fig. 1B) (Boon et al. 1994; Vikkula et al. 1996; Wouters et al. 2010). In $42 \%$ of patients, VM is associated with elevated D-dimers. This correlates with the size and depth of the lesion and the presence of phleboliths (Dompmartin et al. 2008, 2009). Histologically, VMs are characterized by enlarged channels covered by a single layer of endothelial cells and irregular patchy vascular smooth muscle cells (vSMCs) (Vikkula et al. 1996).

VMCM is mediated by mutations in the endothelial-cell-specific tyrosine kinase receptor TIE2 (TEK), on chromosome 9p21. So far, eight activating mutations have been described in 17 families (Vikkula et al. 1996; Calvert et al. 1999; Nobuhara et al. 2006; Wouters et al. 2010). Among these, R849W is the most frequent, accounting for $60 \%$. A somatic second hit has also been identified in lesion-derived cDNA from a patient carrying the inherited R849W mutation. The somatic mutation partially deletes the Ig2 ligand-binding domain of the wild-type allele, resulting in loss of function (Limaye et al. 2009). Interestingly, somatic TIE2 mutations have been found in $50 \%$ of sporadic VMs (Limaye et al. 2009; J Soblet, N Limaye, M Uebelhoer et al., unpubl.). About $70 \%$ of unifocal VMs had an L914F change, which has not been seen as an inherited mutation. This suggests it to be too deleterious when germline. Another 20\% had pairs of mutations occurring in cis, which seem to be enriched in multifocal, sporadic VM (Limaye et al. 2009).

Three known ligands bind TIE2: angiopoietin 1 (ANGPT1), angiopoietin 2 (ANGPT2), and angiopoietin 4 (ANGPT4; Angpt3 in mice) (Maisonpierre et al. 1997; Valenzuela et al. 1999). Whereas ANGPT1 activates TIE2 phosphorylation, ANGPT2 is considered a context-dependent modulator of TIE2 activity (Gale et al. 2002; Yuan et al. 2009). Upon ligand binding, TIE2 receptors dimerize and crossphosphorylate, resulting in the activation of the PI3K/Akt and MAPK pathways, which modulate EC survival, proliferation, and migration, as well as tube formation and sprouting (Kontos et al. 1998; Harfouche et al. 2003). All of the VM-mutant forms induce ligand-independent hyperphosphorylation of the receptor in vitro, to widely varying degrees (Vikkula et al. 1996; Calvert et al. 1999; Limaye et al. 2009; Wouters et al. 2010), without causing EC proliferation (Vikkula et al. 1996; Calvert et al. 1999). Thus, it is unknown how they cause lesions.

The R849W mutant maintains an ShcAand pAkt-mediated prosurvival effect on ECs (Morris et al. 2005), which could explain their abundance in lesions and the increased instability of tube formation by HUVECs expressing mutant TIE2 in vitro. R849W-TIE2 also induces STAT1 activation in HUVECs $(\mathrm{Hu}$ et al 2008) and increased STAT3 and 5 activation in HEK293 (Korpelainen et al. 1999). On the other hand, ANGPT1 stimulation of TIE2 can induce expression of apelin, a ligand for the G-protein-coupled receptor APJ, which regulates blood vessel caliber (Kidoya et al. 2008). The ANGPT1-TIE2 system also up-regulates hepatocyte growth factor (HGF) secretion to induce vSMC recruitment (Kobayashi et al. 2006). HGF might therefore have a role in the impaired vSMC recruitment and relative lack of vSMCs in VMs. Finally, TIE2 can form heteroduplexes with TIE1, which plays an inhibitory role by down-regulating ANGPT1TIE2-mediated Akt and MAPK phosphorylation (Hansen et al. 2010; Seegar et al. 2010). It is also necessary to distinguish between the agonistic and antagonistic effects of ANGPT2 on TIE2 signaling (Seegar et al. 2010).

Targeted gene disruptions of Tie2, Angpt1, or Angpt2 in mice result in profoundly defective remodeling and maturation of blood vessels during angiogenesis. Tie2-deficient mice die at 
mid-gestation with insufficient remodeling of the primary capillary plexus (Dumont et al. 1994; Sato et al. 1995). Angpt1 ${ }^{-/-}$mice die by E12.5 with a similar phenotype, and reduced association of ECs with SMCs and underlying matrix (Suri et al. 1996). Mice overexpressing Angpt1 in the skin develop more, larger, and more highly branched vessels (Suri et al. 1998). Angpt $2^{-/-}$mice die perinatally from defective remodeling and lymphatic dysfunction. Poor retinal vascularization is observed (Gale et al. 2002). Transgenic overexpression of Angpt2 has similar effects as Angpt1 deficiency (Maisonpierre et al. 1997), supporting the hypothesis that Angpt2 can block the activating effect of Angpt1 by acting as a natural antagonist.

Current treatment of VMs is based on destruction of abnormal vessel lumens by sclerotherapy (with alcohol or other agents toxic to the endothelium), or removal by surgery. Depending on anatomic location, both approaches may be of limited use, and regrowth is often seen. Therefore, there is great need for better treatments. To this end, we are generating mouse models that carry the common inherited or somatic Tie2 mutation, the expression of which can be modulated using Cre-recombinase. If following induction they develop VMs, these mice can be used to study etiopathology as well as potential rescue, either by using known TIE2 inhibitors (Semones et al. 2007; Mori et al. 2008) or by screening for novel small molecule inhibitors. This would allow for the development of more effective, targeted therapies.

\section{Glomuvenous Malformation}

Glomuvenous malformations (GVMs) are raised, pink to purple-blue, often cobblestonelike lesions. They are mostly located on the extremities and involve the skin and subcutis, but rarely the mucosa (Fig. 1C). These multifocal, often hyperkeratotic lesions are painful upon palpation and cannot be completely emptied by compression (Boon et al. 2004; Boon and Vikkula 2008).

GVM is inherited as an autosomal-dominant disorder linked to chromosome 1p21-22.
It is caused by loss-of-function mutations in glomulin (GLMN/FAP68) (Brouillard et al. 2002), leading to abnormally differentiated vSMCs called "glomus cells," around distended vascular channels (Goodman and Abele 1971; Brouillard et al. 2008). Of the more than 30 mutations identified in more than 100 families, 11 account for $>80 \%$ of patients (Brouillard, et al. 2002, 2005, 2008; O'Hagan et al. 2006; P Brouillard, LM Boon, JB Mullikan, et al., unpubl.). The identification of the first somatic second-hit in a vascular anomaly, a 5-bp deletion in glomulin, provided evidence for a paradominant mode of inheritance (Brouillard et al. 2002). At present, 13 somatic second-hits have been identified in GVM tissues from patients with an inherited mutation (Brouillard et al. 2002; M Amyere, V Aerts, P Brouillard, et al., unpubl.), showing the need for complete local loss of glomulin function for lesion formation.

Glomulin interacts with the unphosphorylated HGF receptor c-Met. Binding of HGF, a mediator of SMC migration (Taher et al. 2002), to its receptor induces phosphorylation of glomulin and its release from the receptor. Up-regulation of the p70S6 kinase, a downstream target of PI3K, ensues (Grisendi et al. 2001). Glomulin also interacts with Cul7, forming an Skp1-Cul1-Fbox (SCF)-like complex, which may have a role in protein degradation via ubiquitination (Arai et al. 2003).

Glomulin is specifically expressed in vSMCs and seems to be involved in their differentiation (McIntyre et al. 2004). The transforming growth factor- $\beta$ (TGF- $\beta$ ) signaling pathway is important for vSMC differentiation (Chen et al. 1997). TGF- $\beta$ signaling can be inhibited by binding of the FK506 binding protein 12 (FKBP12) to the TGF- $\beta$ type I receptor (T $\beta R I)$ (Grisendi et al. 2001). In vitro, glomulin can interact with FKBP12 (Chambraud et al. 1996; Grisendi et al. 2001). FKBP12-glomulin complex formation is inhibited by FK506 and rapamycin (Chambraud et al. 1996), leading to the hypothesis that glomulin may play a part in the mTOR signaling pathway.

Possible targets for GVM therapy might thus be the TGF- $\beta$-signaling pathway and 
M. Uebelhoer et al.

modulators of mTOR. The lack of glomulin in glomus cells may liberate FKBP12 to bind to T $\beta R I$, inhibiting TGF- $\beta$ signaling and differentiation of vSMCs. By sequestering FKBP12 in a complex unable to bind the receptor, rapamycin might counteract this inhibition. On the other hand, the absence of a possibly inhibiting FKBP12-glomulin complex may lead to an elevated mTOR activity. Rapamycin, a potent inhibitor of mTOR, could rescue this as well (Thomas and Hall 1997).

These approaches could complement the current treatment of GVMs, which is based on surgical resection, sometimes combined with sclerotherapy (Boon and Vikkula 2008). We are generating mice with inducible downregulation of glomulin, which should allow us to generate vSMC precursors that are devoid of glomulin, leading to development of GVM-like lesions. If so, these mice could be used to study modulators of SMC differentiation for the treatment of GVMs (P Brouillard, pers. comm.).

\section{CAPILLARY MALFORMATION}

Capillary malformations (CM; MIM 163000), commonly called "port-wine stains," are the most common cutaneous vascular malformations, affecting $0.3 \%$ of newborns (Jacobs and Walton 1976). Lesions appear sporadically as flat, red-to-purple stains that mainly involve the head and neck (Fig. 1E). They consist of dilated capillary-like vessels, sometimes increased in number (Boon and Vikkula 2008).

\section{$\mathrm{CM}$ with Arteriovenous Malformation (CM-AVM)}

A distinct subentity of CM, CM associated with arteriovenous malformation (CM-AVM; MIM 608354), is characterized by small multifocal red or brownish CMs, often surrounded by a pale halo (Fig. 1E) (Boon et al. 2005; Revencu et al. 2008a). Such CMs are often associated with a fast-flow lesion (30\%), such as an arteriovenous fistula (AVF), an AVM (Fig. 1D), or a Parkes Weber syndrome (PKWS) (Revencu et al. 2008a).
Autosomal-dominant inheritance allowed us to identify the responsible gene, RASA1, on 5q13-22 (Breugem et al. 2002; Eerola et al. 2002, 2003). So far, more than 40 truncating loss-of-function mutations have been identified in about 100 families (Eerola et al. 2003; Hershkovitz et al. 2008; Revencu et al. 2008a; N Revencu, LM Boon, JB Mulliken, et al., unpubl.). The phenotypic heterogeneity and slightly reduced penetrance (98\%) suggest that a somatic second-hit is involved in lesion formation, as in VMCMs and GVMs.

The encoded protein, p120RasGAP, negatively regulates the Ras/MAPK pathway. Following activation, p120RasGAP is recruited to the cell surface (alone or with Annexin A6), where it inactivates Ras by enhancing its weak intrinsic GTPase activity, generating inactive GDP-bound Ras (Grewal et al. 2005). p120RasGAP plays a role in regulation of cell polarity and motility by interacting with FAK and p190RhoGAP (Kulkarni et al. 2000). It also protects cells from apoptosis by binding to Akt (Yue et al. 2004). Furthermore, it can inhibit the Rho-GAP activity of DLC1, thereby decreasing the growth-suppressive activity of the latter (Yang et al. 2009). It is unknown which of these pathways are dysfunctional in CM-AVM (Revencu et al. 2008b).

Rasa1 ${ }^{+/-}$mice are normal, but Rasa1 ${ }^{-/-}$ mice die in utero at E10.5, from defective vascular development and increased apoptosis (Henkemeyer et al. 1995). The mice mosaic for $\mathrm{Rasa1}^{-/-}$and Rasal ${ }^{+/+}$cells develop localized vascular dysplasia, underscoring the paradominant inheritance of CM-AVM (Henkemeyer et al. 1995). Current therapy of CMs is mainly based on laser. This procedure is painful and requires several sessions, and only limited areas can be treated. Treatment of AVM is even more difficult. Partial surgery and inadequate embolization often aggravate the lesion, and complete surgical resection is rarely possible.

Murine models of CM-AVM may allow for the testing of Ras inhibitors as possible therapies. These include dominant-negative Ras, anti-Ras antibodies, inhibitors targeting the Ras-signaling pathway, and inhibitors directed against PI3K or MEK (Gottfried et al. 2010). 
Rapamycin has been shown to inhibit mTOR activation in neurofibromatosis, in which loss of NF1 leads to deregulation of Ras and, in turn, activation of mTOR (Johannessen et al. 2005). Given the homology between NF1 and RASA1, it may be that rapamycin is efficient in CM-AVM.

\section{Cerebral Cavernous Malformation (CCM)}

Cerebral cavernous (or capillary-venous) malformations (CCMs; MIM 116860) occur in $\sim 0.5 \%$ of the population. They are mostly sporadic $(80 \%)$ but can occur as an autosomal-dominantly inherited trait (20\%). Patients often have seizures, headaches, neurological problems, and cerebral hemorrhages, although some are asymptomatic (Rigamonti et al. 1988; Revencu and Vikkula 2006). Lesions are mostly localized in the brain, but also in the spinal cord and the retina, and are sometimes accompanied by cutaneous vascular lesions. Although sporadic patients usually have a single lesion, familial CCMs are characterized by multifocal lesions (Revencu and Vikkula 2006). Histologically, CCMs consist of dilated capillary-like vessels surrounded by a defective layer of ECs lacking tight junctions, resulting in inter-EC gaps (Revencu and Vikkula 2006).

Four loci have been identified for the autosomal-dominant CCMs: CCM1 on 7q11-22 with mutations in KRIT1 (KREV1 interaction trapped 1) (Laberge-le Couteulx et al. 1999); CCM2 on 7p13 with mutations in MGC4607 or malcavernin (Liquori et al. 2003); CCM3 on 3q26.1 with mutations in PDCD10 (Bergametti et al. 2005); and CCM4 on 3q26.3-27.2 (Liquori et al. 2006). To date, more than 150 mutations, mostly resulting in loss of function, have been reported in CCM1-3. Like for VMCM and GVM, double-hits have been identified for each of the three CCM genes in a few lesions (Revencu and Vikkula 2006; Riant et al. 2010).

The three CCM proteins interact with each other, with CCM2 acting as a linker between CCM1 and CCM3 (Zawistowski et al. 2005; Voss et al. 2007). They form a complex with MEKK3, the small GTPase RAC1, and ICAP- $1 \alpha$, which acts downstream from the integrin signaling pathway, as well as the p38MAPK pathway (Fig. 2) (Zhang et al. 2001; Uhlik et al. 2003). The interaction of KRIT1 with the small GTPase Rap1 (Serebriiskii et al. 1997; Glading et al. 2007), a known stabilizer of EC junctions, may have a role in the regulation of cell-cell junctions and lead to a defective EC layer in CCMs. Furthermore, CCM1 promotes DLL4-NOTCH signaling, inducing phosphorylation of AKT and inhibiting phosphorylation of ERK, which might explain the elevated levels of phosphorylated ERK in human CCM lesions (Fig. 2) (Wustehube et al. 2010). CCM1, -2, or -3 knockdown in vitro results in increased expression of RhoA, and inhibition of EC tube formation and ECM invasion (Borikova et al. 2010; Stockton et al. 2010).

In zebrafish, lack of CCM1, 2, or 3 results in dilated thin-walled vessels because of abnormal EC sprouting (Hogan et al. 2008; Voss et al. 2009). $\mathrm{Ccm}^{+/-}$and $C \mathrm{~cm} 2^{+/-}$mice are healthy with no vascular lesions, whereas homozygous $\mathrm{Ccm}^{-/-}$and $\mathrm{Ccm} 2^{-/-}$mice die around mid-gestation from vascular defects (Whitehead et al. 2004; Plummer et al. 2006). However, heterozygous $\mathrm{Ccm} 2^{+/-}$mice have abnormal vascular leakage in response to VEGF (Whitehead et al. 2009). $\mathrm{Ccml}^{+/-}$ $\operatorname{Trp}_{53} 3^{-/}$mice, heterozygous for $\mathrm{Ccm} 1$ and deficient for the tumor suppressor Trp53, develop vascular brain lesions similar to those seen in CCM patients (Plummer et al. 2004). Whereas neural- and SMC-specific depletion of $\mathrm{Ccm} 2$ has no effect, EC-specific loss of $\mathrm{Ccm} 2$ or Pdcd10 in mice results in formation of CCMs (Boulday et al. 2009; Whitehead et al. 2009; Chan et al. 2011). The pathways involved in lesion formation are, however, different: Whereas loss of Krit1 or Ccm2 leads to RhoA activation, Pdcd10 binds GCKIII (germinal center kinase III) family kinases and plays a role in EC lumen formation (Chan et al. 2011).

Transplantation of CCM1-depleted HUVECs into SCID mice leads to development of an irregular hyperdense vasculature and enlarged vessels. This can be rescued by treatment with the multikinase inhibitor sorafenib, an antiangiogenic agent (Wustehube et al. 2010). Antiangiogenic therapy might thus be a potential 
M. Uebelhoer et al.

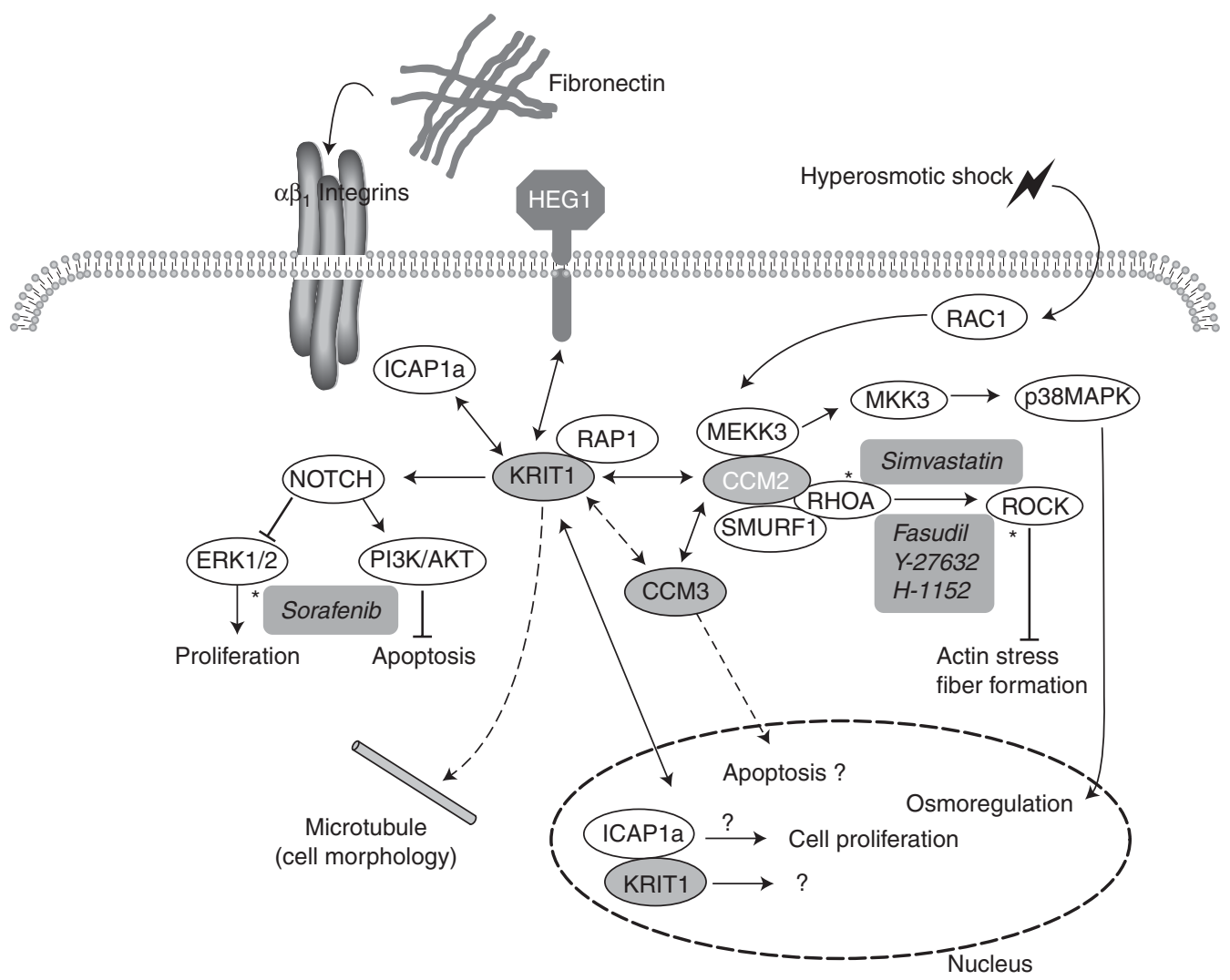

Figure 2. Schematic presentation of pathways involved in CCM: KRIT1, CCM2, or CCM3 mutated (highlighted in gray); hypothetical interactions (dashed lines). Candidate molecules for targeted therapy (italic, highlighted in gray); the site of action is marked by an asterisk.

alternative for surgery, the current treatment for CCM patients. More targeted inhibitors, however, might be beneficial to reduce side effects. On the basis of the biological findings, inhibitors of RhoA or ROCK might be good candidates (Fig. 2). Vascular leakage in $\mathrm{Ccm}^{+/-}$mice is rescued by treatment with simvastatin, a known inhibitor of RhoA (Whitehead et al. 2009). The chemical inhibitor of ROCK, Y-27632, reverses the CCM phenotype resulting from a CCM1, -2 , or -3 knockdown in vitro (Borikova et al. 2010), and the other inhibitor, fasudil, cannot only reverse the effects of CCM1 or 2 deficiency in vitro, but also in vivo in heterozygous mutant mice (Stockton et al. 2010). Fasudil is well tolerated in animals and has already been used in humans for treatment of other diseases (Olson 2008).
Hereditary Hemorrhagic Telangiectasia (HHT)

Hereditary hemorrhagic telangiectasia (HHT; MIM 187300), also known as Osler-RenduWeber syndrome, is an autosomal-dominantly inherited disorder with an incidence of $1 /$ $5000-1 / 8000$ (Govani and Shovlin 2009). It is characterized by cutaneomucosal and gastrointestinal telangiectasias (Fig. 1F), often associated with multiple AVMs or AVFs in the lungs, liver, brain, or gastrointestinal tract (Govani and Shovlin 2009). Telangiectasias are focal dilatations of post-capillary venules, surrounded by extensive layers of SMCs, with direct connections to dilated arterioles in the absence of an intervening capillary bed. Patients suffer from recurrent and significant epistaxis (Govani and Shovlin 2009). 
Four different loci have been linked with HHT: HHT1 on 9q33-34 with mutations in endoglin (ENG) (McAllister et al. 1994); HHT2 on 12q11-14 with mutations in activin receptor-like kinase $1(A L K)$ (Johnson et al. 1996); HHT3 on $5 q$ (Cole et al. 2005); and HHT4 on 7p14 (Bayrak-Toydemir et al. 2006). Mutations in MADH4 on 18q21.1, encoding SMAD4, cause juvenile polyposis/HHT syndrome (JPHT; MIM 175050) (Gallione et al. 2004). To date, more than 300 mutations in ENG and at least 250 mutations in ALK have been reported, all of which result in haploinsufficiency (Govani and Shovlin 2009).

Endoglin and ALK1 are expressed in ECs and were originally thought to cause HHT via defects in TGF- $\beta$ signaling: In the presence of TGFBR2, TGF- $\beta 1$ binds ALK1 or ALK5, which activate SMAD1/5/8 or SMAD2/3, respectively. Although signaling through ALK1 sometimes induces and sometimes inhibits EC migration and proliferation, signaling through ALK5 has an inhibitory effect (Oh et al. 2000; Goumans et al. 2002). ENG modulates this response (Lebrin et al. 2004). It was hypothesized that the abnormal vasculature in HHT resulted from the impaired balance between ALK5 and ALK1 (Goumans et al. 2002; Lebrin et al. 2004). However, in mice, Alk1 is mostly expressed in ECs, whereas Alk5 is expressed in SMCs (Seki et al. 2006). At present, BMP9 and -10 signaling is being recognized as more important for the pathogenesis of HHT. Binding of BMP9 and 10 to ALK1 or ENG, in the presence of BMPRII, inhibits EC proliferation and migration (Fig. 3) (David et al. 2007; Park et al. 2008).

SMAD4 is a ubiquitously expressed intracellular TGF- $\beta$ receptor signal transducer that binds to SMAD1, $-2,-3,-5$, and/or -8 and subsequently translocates them to the nucleus (Sirard et al. 1998). Smad4 knockouts die embryonically before E7.5 because of impaired gastrulation (Sirard et al. 1998). The HHT3 and HHT4 genes are likely closely related players with ENG, ALK1, and SMAD4.

Alk1 and Eng knockout mice are embryonically lethal at E10.5-E11.5 (Bourdeau et al. 1999; Oh et al. 2000), whereas heterozygous mice sometimes develop HHT-like lesions (Bourdeau et al. 1999; Srinivasan et al. 2003). Endothelial-cell-specific conditional knockout mice for Alk1 die by E18.5. Embryos have severe vascular malformations comparable with those seen in HHT patients, whereas EC-specific knockouts of Alk5 or Tgf $\beta r 2$ have no effects (Park et al. 2008). This underscores that the latter might not be needed for ALK1 signaling in HHT.

To develop AVMs in adult mice, an angiogenic stimulus is needed in addition to Alk1 deficiency (Park et al. 2009). Abnormally high VEGF levels in heterozygous $A l k^{+/-}$mice suggest that VEGF contributes to the HHT phenotype by promoting angiogenesis (Shao et al. 2009). The inducible, EC-specific endoglin knockout has a delay in the development of the vascular plexus and increased EC proliferation. These mice regularly develop AVMs comparable with those seen in HHT patients. Therefore, the formation of AVMs is dependent on angiogenesis and might require a somatic second-hit (Mahmoud et al. 2010). The murine model will help understand how AVMs are formed in vivo and allow for the development of novel therapies.

To date, few therapeutic options exist to limit blood loss in HHT patients: modulation of coagulation and fibrinolysis, embolization, surgical replacement of nasal epithelium, topical application of anti-inflammatory drugs, or hormonal treatment with estrogens or progesterones. Some newer trials also exist. The immunosuppressor tacrolimus (FK506) significantly increases mRNA and protein levels of ENG and ALK1 in cultured ECs and was shown to reduce telangiectases and epistaxis in one patient (Fig. 3) (Albiñana et al. 2011). Raloxifene is a selective estradiol receptor modulator (SERM) that has had promising clinical results. In vitro, it increases the expression of ALK1 and endoglin, and has a proangiogenic effect by stimulating tube formation and EC migration (Fig. 3) (Albiñana et al. 2010). However, like other SERMs, it increases the risk of thrombotic events (Mosca et al. 2009).

The VEGF inhibitor bevacizumab (trade name Avastin) can specifically target the 
M. Uebelhoer et al.



Figure 3. Schematic presentation of pathways involved in HHT: ALK1, ENG, or SMAD4 mutated. Candidate molecules for targeted therapy (italic, highlighted in gray); the site of action is marked by an asterisk.

elevated VEGF levels seen in HHT patients (Fig. 3) (Shao et al. 2009). By inhibiting cell proliferation and promoting cell death, it diminishes the number of cells and leads to vessel regression (Carmeliet 2005). Administration of Avastin to HHT patients significantly reduces nose bleeds (Karnezis and Davidson 2011).

Thalidomide inhibits EC proliferation and migration, stimulates recruitment of SMCs, and shows an antihemorrhagic effect (Fig. 3) (D'Amato et al. 1994; Therapontos et al. 2009). In endoglin ${ }^{+/-}$mice, it is able to normalize excessive vessel sprouting and restore the deficient SMC layer of arteries in the ear in a PDGF-B-dependent manner (Lebrin et al. 2010). Sections of biopsies from nasal mucosa of HHT patients showed increased SMC layers around blood vessels after treatment with thalidomide (Lebrin et al. 2010). The frequency and duration of nosebleeds in thalidomidetreated patients was also significantly reduced (Lebrin et al. 2010). We have similarly treated HHT patients with good response, although with clinical side effects (LM Boon, pers. comm.).

\section{LYMPHATIC MALFORMATION AND LYMPHEDEMA}

\section{Lymphatic Malformation}

Lymphatic malformations (LMs) are localized, sporadically occurring lesions, often enlarged upon infection. They are composed of dilated lymphatic channels not connected to the lymphatic system but filled with clear fluid (Whimster 1976; Boon and Vikkula 2008). The etiopathogenesis of LM is unknown. Dysfunction of genes expressed during lymphangiogenesis 
and/or in mature lymphatic vessels, including LYVE-1, VEGFR-3, and its ligands VEGF-C and VEGF-D, PROX-1, NRP-2, and ANGPT2, are potential candidates. While awaiting a specific treatment for LMs, rapamycin, an inhibitor of mTOR, has been used in a case series of six patients (Hammill et al. 2011). Rapamycin and its analogs, however, have a variety of side effects, such as immunosuppression, mucositis, pneumonitis, hyperglycemia, hyperlipidemia, and skin rash, and their efficacy and administration should be carefully evaluated.

\section{Primary Lymphedema}

Lymphedema (LE) is characterized by diffuse, localized, or extensive swelling, due to defective lymphatic drainage (Fig. 1G) (Dale 1985; Boon and Vikkula 2008). It can be inherited and is classified into primary and secondary lymphedema. Primary lymphedema is of unknown etiology or known genetic cause, whereas secondary lymphedema develops after an extrinsic factor such as trauma caused by surgery or infection to lymphatic vessels.

\section{Primary Congenital Lymphedema}

Primary hereditary congenital lymphedema (Nonne-Milroy disease; MIM 153100) mainly affects the legs below the knees $(>90 \%)$ and is usually present at birth. Prenatal pleural effusion and hydrops fetalis have also been observed (Daniel-Spiegel et al. 2005; Ghalamkarpour et al. 2006). This autosomal-dominantly inherited disorder is caused by missense mutations in the tyrosine kinase domain of the vascular endothelial growth factor receptor 3 (VEGFR3/FLT4), located on 5q35.3 (Irrthum et al. 2000; Karkkainen et al. 2000; Carver et al. 2007; Ghalamkarpour et al. 2009a,b). De novo mutations have been described in patients with sporadic forms of congenital lymphedema or sporadic hydrops fetalis (Ghalamkarpour et al. 2006, 2009a,b; Carver et al. 2007). In one family with recessively inherited lymphedema, a hypomorphic mutation was identified (Ghalamkarpour et al. 2009b). The mutations inhibit phosphorylation of the receptor and prevent downstream signaling (Irrthum et al. 2000; Karkkainen et al. 2000; Ghalamkarpour et al. $2009 \mathrm{~b})$. The recessive mutation only diminishes phosphorylation via altered ATP binding, therefore requiring homozygosity to express the phenotype (Ghalamkarpour et al. 2009b).

Vegfr $3^{-/-}$mice die embryonically at E9.5 because of abnormally organized vessels, fluid accumulation in the pericardial cavity, and cardiovascular failure (Dumont et al. 1998). Heterozygous Vegfr $3^{+/}$mice appear normal (Dumont et al. 1998). Transgenic mice overexpressing a soluble form of Vegfr3 in the skin develop a lymphedema-like phenotype characterized by swelling of feet, edema, and dermal fibrosis (Makinen et al. 2001). Despite the lack of lymphatic vessels in several tissues, regeneration of the lymphatic vasculature can be observed later on, indicating that induction of lymphatic regeneration may also be possible in patients.

Adenoviral-based inhibition of Vegfr3 signaling leads to regression of lymphatic capillaries and medium-sized lymphatic vessels in mice under 2 wk of age, whereas no effect is observed after this period (Karpanen et al. 2006). This suggests that antilymphangiogenic therapy may safely be applied to adults. Finally, Chy mice are the animal model of Nonne-Milroy disease. They carry a germline inactivating Vegfr3 mutation leading to swelling of the limbs due to hypoplastic cutaneous lymphatic vessels (Karkkainen et al. 2001).

Missense mutations in GJC2, encoding the gap junction protein connexin 47 ( $\mathrm{Cx} 47)$, have been identified in six families with dominantly inherited, non-syndromic lymphedema (Ferrell et al. 2010). These might cause a disruption of lymphatic flow by altering gap junctions. A family with autosomal-dominant lymphedema associated with choanal abnormality was linked to 1q32-q41, with an intragenic deletion in PTPN14. Homozygous Ptpn14 ${ }^{-/-}$gene trap mice grow slower than wild-type mice, and $\sim 14 \%$ develop peritoneal edemas and swelling of the limbs. Lymphatic hyperplasia and capillary leakage can be observed (Au et al. 2010). Other genes that may be implicated in lymphedema are neuropilin-2 (NRP-2), SOX17, 
M. Uebelhoer et al.

VCAM1, HGF, and its receptor $c$-MET, for which rare changes have been reported in some patients (Ferrell et al. 2008; Finegold et al. 2008). Moreover, primary congenital resolving lymphedema has been linked to a 6q16.2-22.1 locus (Malik and Grzeschik 2008).

\section{Late-Onset Lymphedema}

Late-onset lymphedema (Meige disease; 153200) develops around puberty. It can be associated with distichiasis (lymphedema distichiasis, LD; MIM 153400), sometimes accompanied by ptosis (lymphedema and ptosis; MIM 153000) or yellow nails (yellow nail syndrome; MIM 153300) (Fang et al. 2000; Bell et al. 2001; Finegold et al. 2001). Loss-of-function mutations in the Forkhead transcription factor FOXC2 on 16q24.3 have been identified in families with LD (Fang et al. 2000; Bell et al. 2001; Finegold et al. 2001). FOXC2 is implicated in the regulation of angiogenesis and vascular remodeling by controlling the expression of ANGPT2, the TIE2 ligand (Xue et al. 2008); of integrins and fibronectin, interactors with the extracellular matrix (Hayashi et al. 2008); and of Dll4 and Hey2 (Hayashi and Kume 2008).

Heterozygous Foxc $2^{+/-}$mice are viable and develop generalized lymphatic vessel and lymph node hyperplasia, and rarely hindlimb swelling (Kriederman et al. 2003). They have distichiasis and thus provide an animal model for LD. Homozygous Foxc2 $2^{-/-}$mice die embryonically or perinatally with abnormal lymphatic patterning (Winnier et al. 1997). They have increased pericyte investment of lymphatic vessels, because of overexpression of the platelet-derived growth factor b (Pdgfb), as well as agenesis of valves and lymphatic dysfunction (Petrova et al. 2004).

\section{Hypotrichosis-Lymphedema-Telangiectasia Syndrome (HLTS)}

Hypotrichosis-lymphedema-telangiectasia syndrome (HLTS; MIM 607823) is rare and consists of lymphedema associated with sparse hair and cutaneous telangiectasias. It is mediated by mutations in the transcription factor SOX18, an early lymphatic marker, the gene of which is located on 20q13.33. Autosomal-dominant mutations in the transactivation domain and a homozygous recessive substitution in the DNAbinding domain have been reported (Irrthum et al. 2003; Ghalamkarpour et al. 2008).

SOX18 is expressed in ECs, in hair and feather follicles, and in the heart. It can activate transcription of PROX1, an early marker for lymphatic vessel differentiation. PROX1 interacts with the transcription factor MEFC2, which directly regulates the expression of the EC adhesion molecule VCAM1 (Ghalamkarpour et al. 2008). Although SOX18 seems to play a redundant role with SOX7 and 17 for arterio-venous specification, it is essential for lymph/vascular development (Ghalamkarpour et al. 2008). Thus, mice lacking Sox18 die from severe edema and lack of lymphatic EC differentiation from cardinal veins (Pennisi et al. 2000a). Mutations in Sox18 cause cardiovascular and hair follicle defects in ragged ( $\mathrm{Ra}$ ) mice, which have a phenotype similar to the human disorder HLTS. Homozygous Ra mice are naked and perinatally lethal because of generalized edema, chylous ascites, and cyanosis (Pennisi et al. 2000b).

The current therapy for lymphedema consists of complex decongestive physiotherapy to reduce limb volume and maintain the health of the skin and supporting structures. Lymphatic-specific massage and manual lymphatic drainage (MLD), as well as skin care, exercise, and the use of compression bandages, are the gold standard. Occasionally surgery is performed (Rockson 2008). These treatments can cause improvement but are only symptomatic and do not repair the underlying dysfunction.

Growth factor gene therapy might be applicable to lymphedema. Administration of the VEGF-C gene or protein reduces lymphedema in preclinical studies (Szuba et al. 2002). A virus-mediated VEGF-C gene therapy results in the formation of lymphatic vessels in Chy mice (Karkkainen et al. 2001). Adenoviral administration of VEGF-C or VEGF-D to lymph-node-excised mice induces growth of lymphatic capillaries and the formation of functional lymphatic vessels (Tammela et al. 2007). 
Moreover, local intradermal transfection of VEGF-C in the hindlimb of rats with secondary lymphedema produces new lymphatic vessels, improves lymphatic drainage, and reduces lymphedema volume (Liu et al. 2008). Because primary lymphedema seems multifactorial and multiple genetic loci are involved, better understanding of the numerous predisposing genetic factors is needed for the development of good models.

\section{CONCLUDING REMARKS}

The era of molecular classification of lymphatic and vascular anomalies has clearly dawned. Several genes, mutations in which explain the development of lesions, have been identified. For phenotypes that can be caused by various genes, a molecular name may become useful: for example, "VEGFR3-lymphedema" instead of "Milroy's disease." It may, however, be difficult to change the clinical language and the established nomenclature. At any rate, our understanding of the molecular pathways leading to these disorders gives us the possibility of generating murine models that carry exactly the same genetic defects. Such models and our increasing knowledge of the exact alterations and their effects allow us to imagine, design, and develop novel approaches to treatment. While awaiting mutation-specific targeted therapies, the use of known lymphangiogenesis and/or angiogenesis modulators, immunomodulators, and anticancer drugs may provide useful alternatives for faster development of novel therapies, albeit with side effects that need careful monitoring.

\section{ACKNOWLEDGMENTS}

M.U. was supported by a fellowship from F.R.S.-FNRS-Télévie, Belgium. Our studies were partially supported by the F.R.S.-FNRS (Fonds National de la Recherche Scientifique); the Interuniversity Attraction Poles initiated by the Belgian Federal Science Policy, networks 5/25 and 6/05; Concerted Research Actions (A.R.C.) - Conventions Nos 02/07/276 and 7/ 12-005 of the Belgian French Community
Ministry; and the National Institutes of Health program project PO1 AR048564-01A1 (all to M.V.). We thank Liliana Niculescu for her superb secretarial help.

\section{REFERENCES}

Albiñana V, Bernabeu-Herrero ME, Zarrabeitia R, Bernabeu C, Botella LM. 2010. Estrogen therapy for hereditary haemorrhagic telangiectasia (HHT): Effects of raloxifene, on endoglin and ALK1 expression in endothelial cells. Thromb Haemost 103: 525-534.

Albiñana V, Sanz-Rodriguez F, Recio-Poveda L, Bernabéu C, Botella LM. 2011. Immunosuppressor FK506 increases endoglin and activin receptor-like kinase 1 expression and modulates transforming growth factor$\beta 1$ signaling in endothelial cells. Mol Pharmacol 79: 833-843.

Annabi B, Lachambre MP, Plouffe K, Moumdjian R, Beliveau R. 2009. Propranolol adrenergic blockade inhibits human brain endothelial cells tubulogenesis and matrix metalloproteinase-9 secretion. Pharmacol Res 60: $438-445$.

Arai T, Kasper JS, Skaar JR, Ali SH, Takahashi C, DeCaprio JA. 2003. Targeted disruption of $p p 185 / C u l 7$ gene results in abnormal vascular morphogenesis. Proc Natl Acad Sci 100: 9855-9860.

Au AC, Hernandez PA, Lieber E, Nadroo AM, Shen YM, Kelley KA, Gelb BD, Diaz GA. 2010. Protein tyrosine phosphatase PTPN14 is a regulator of lymphatic function and choanal development in humans. Am J Hum Genet 87: 436-444.

Bayrak-Toydemir P, McDonald J, Akarsu N, Toydemir RM, Calderon F, Tuncali T, Tang W, Miller F, Mao R. 2006. A fourth locus for hereditary hemorrhagic telangiectasia maps to chromosome 7. Am J Med Genet A 140: 2155-2162.

Bell R, Brice G, Child AH, Murday VA, Mansour S, Sandy CJ, Collin JR, Brady AF, Callen DF, Burnand K, et al. 2001. Analysis of lymphoedema-distichiasis families for FOXC2 mutations reveals small insertions and deletions throughout the gene. Hum Genet 108: 546-551.

Bergametti F, Denier C, Labauge P, Arnoult M, Boetto S, Clanet M, Coubes P, Echenne B, Ibrahim R, Irthum B, et al. 2005. Mutations within the programmed cell death 10 gene cause cerebral cavernous malformations. Am J Hum Genet 76: 42-51.

Blei F, Walter J, Orlow SJ, Marchuk DA. 1998. Familial segregation of hemangiomas and vascular malformations as an autosomal dominant trait. Arch Dermatol 134: $718-722$.

Boon LM, Vikkula M. 2008. Vascular malformations. In Fitzpatrick's dermatology in general medicine, 7th ed. (ed. Wolff K, et al.), Vol. 2, pp. 1651-1666. McGrawHill, New York.

Boon LM, Mulliken JB, Vikkula M, Watkins H, Seidman J, Olsen BR, Warman ML. 1994. Assignment of a locus for dominantly inherited venous malformations to chromosome 9p. Hum Mol Genet 3: 1583-1587. 
M. Uebelhoer et al.

Boon LM, MacDonald DM, Mulliken JB. 1999. Complications of systemic corticosteroid therapy for problematic hemangioma. Plast Reconstr Surg 104: 1616-1623.

Boon LM, Mulliken JB, Enjolras O, Vikkula M. 2004. Glomuvenous malformation (glomangioma) and venous malformation: Distinct clinicopathologic and genetic entities. Arch Dermatol 140: 971-976.

Boon LM, Mulliken JB, Vikkula M. 2005. RASA1: Variable phenotype with capillary and arteriovenous malformations. Curr Opin Genet Dev 15: 265-269.

Borikova AL, Dibble CF, Sciaky N, Welch CM, Abell AN, Bencharit S, Johnson GL. 2010. Rho kinase inhibition rescues the endothelial cell cerebral cavernous malformation phenotype. J Biol Chem 285: 11760-11764.

Boscolo E, Bischoff J. 2009. Vasculogenesis in infantile hemangioma. Angiogenesis 12: 197-207.

Boulday G, Blecon A, Petit N, Chareyre F, Garcia LA, NiwaKawakita M, Giovannini M, Tournier-Lasserve E. 2009. Tissue-specific conditional CCM2 knockout mice establish the essential role of endothelial CCM2 in angiogenesis: Implications for human cerebral cavernous malformations. Dis Model Mech 2: 168-177.

Bourdeau A, Dumont DJ, Letarte M. 1999. A murine model of hereditary hemorrhagic telangiectasia. J Clin Invest 104: 1343-1351.

Breugem CC, Alders M, Salieb-Beugelaar GB, Mannens MM, Van der Horst CM, Hennekam RC. 2002. A locus for hereditary capillary malformations mapped on chromosome 5q. Hum Genet 110: 343-347.

Brouillard P, Boon LM, Mulliken JB, Enjolras O, Ghassibe M, Warman ML, Tan OT, Olsen BR, Vikkula M. 2002. Mutations in a novel factor, glomulin, are responsible for glomuvenous malformations ("glomangiomas"). Am J Hum Genet 70: 866-874.

Brouillard P, Ghassibe M, Penington A, Boon LM, Dompmartin A, Temple IK, Cordisco M, Adams D, Piette F, Harper JI, et al. 2005. Four common glomulin mutations cause two thirds of glomuvenous malformations ("familial glomangiomas"): Evidence for a founder effect. J Med Genet 42: e13. doi: 10.1136/jmg.2004.024174.

Brouillard P, Enjolras O, Boon LM, Vikkula M. 2008. Glomulin and glomuvenous malformation. In Inborn errors of development, 2nd ed. (ed. Epstein CJ, et al.), pp. 1561-1565. Oxford University Press, Oxford.

Calvert JT, Riney TJ, Kontos CD, Cha EH, Prieto VG, Shea CR, Berg JN, Nevin NC, Simpson SA, Pasyk KA, et al. 1999. Allelic and locus heterogeneity in inherited venous malformations. Hum Mol Genet 8: 1279-1289.

Carmeliet P. 2005. VEGF as a key mediator of angiogenesis in cancer. Oncology 69: 4-10.

Carmeliet P, Ferreira V, Breier G, Pollefeyt S, Kieckens L, Gertsenstein M, Fahrig M, Vandenhoeck A, Harpal K, Eberhardt C, et al. 1996. Abnormal blood vessel development and lethality in embryos lacking a single VEGF allele. Nature 380: 435-439.

Carver C, Brice G, Mansour S, Ostergaard P, Mortimer P, Jeffery S. 2007. Three children with Milroy disease and de novo mutations in VEGFR3. Clin Genet 71: 187-189.

Chambraud B, Radanyi C, Camonis JH, Shazand K, Rajkowski K, Baulieu EE. 1996. FAP48, a new protein that forms specific complexes with both immunophilins
FKBP59 and FKBP12. Prevention by the immunosuppressant drugs FK506 and rapamycin. J Biol Chem 271: 32923-32929.

Chan AC, Drakos SG, Ruiz OE, Smith AC, Gibson CC, Ling J, Passi SF, Stratman AN, Sacharidou A, Revelo MP, et al. 2011. Mutations in 2 distinct genetic pathways result in cerebral cavernous malformations in mice. J Clin Invest 121: $1871-1881$.

Chang J, Most D, Bresnick S, Mehrara B, Steinbrech DS, Reinisch J, Longaker MT, Turk AE. 1999. Proliferative hemangiomas: Analysis of cytokine gene expression and angiogenesis. Plast Reconstr Surg 103: 1-9.

Chen YG, Liu F, Massague J. 1997. Mechanism of TGF $\beta$ receptor inhibition by FKBP12. EMBO J 16: 3866-3876.

Chiller KG, Passaro D, Frieden IJ. 2002. Hemangiomas of infancy: Clinical characteristics, morphologic subtypes, and their relationship to race, ethnicity, and sex. Arch Dermatol 138: 1567-1576.

Cole SG, Begbie ME, Wallace GM, Shovlin CL. 2005. A new locus for hereditary haemorrhagic telangiectasia (HHT3) maps to chromosome 5. J Med Genet 42: 577-582.

Dale RF. 1985. The inheritance of primary lymphoedema. $J$ Med Genet 22: 274-278.

D’Amato RJ, Loughnan MS, Flynn E, Folkman J. 1994. Thalidomide is an inhibitor of angiogenesis. Proc Natl Acad Sci 91: 4082-4085.

Daniel-Spiegel E, Ghalamkarpour A, Spiegel R, Weiner E, Vikkula M, Shalev E, Shalev SA. 2005. Hydrops fetalis: An unusual prenatal presentation of hereditary congenital lymphedema. Prenat Diagn 25: 1015-1018.

David L, Mallet C, Mazerbourg S, Feige JJ, Bailly S. 2007. Identification of BMP9 and BMP10 as functional activators of the orphan activin receptor-like kinase 1 (ALK1) in endothelial cells. Blood 109: 1953-1961.

Dompmartin A, Acher A, Thibon P, Tourbach S, Hermans C, Deneys V, Pocock B, Lequerrec A, Labbe D, Barrellier MT, et al. 2008. Association of localized intravascular coagulopathy with venous malformations. Arch Dermatol 144: $873-877$.

Dompmartin A, Ballieux F, Thibon P, Lequerrec A, Hermans C, Clapuyt P, Barrellier MT, Hammer F, Labbe D, Vikkula $\mathrm{M}$, et al. 2009. Elevated D-dimer level in the differential diagnosis of venous malformations. Arch Dermatol 145: 1239-1244.

Dompmartin A, Vikkula M, Boon LM. 2010. Venous malformation: Update on aetiopathogenesis, diagnosis and management. Phlebology 25: 224-235.

Dumont DJ, Gradwohl G, Fong GH, Puri MC, Gertsenstein M, Auerbach A, Breitman ML. 1994. Dominant-negative and targeted null mutations in the endothelial receptor tyrosine kinase, tek, reveal a critical role in vasculogenesis of the embryo. Genes Dev 8: 1897-1909.

Dumont DJ, Jussila L, Taipale J, Lymboussaki A, Mustonen T, Pajusola K, Breitman M, Alitalo K. 1998. Cardiovascular failure in mouse embryos deficient in VEGF receptor-3. Science 282: 946-949.

Eerola I, Boon LM, Watanabe S, Grynberg H, Mulliken JB, Vikkula M. 2002. Locus for susceptibility for familial capillary malformation ("port-wine stain") maps to 5q. Eur J Hum Genet 10: 375-380. 
Eerola I, Boon LM, Mulliken JB, Burrows PE, Dompmartin A, Watanabe S, Vanwijck R, Vikkula M. 2003. Capillary malformation-arteriovenous malformation, a new clinical and genetic disorder caused by RASAl mutations. Am J Hum Genet 73: 1240-1249.

Enjolras O, Breviere GM, Roger G, Tovi M, Pellegrino B, Varotti E, Soupre V, Picard A, Leverger G. 2004. Vincristine treatment for function- and life-threatening infantile hemangioma. Arch Pediatr 11: 99-107.

Fang J, Dagenais SL, Erickson RP, Arlt MF, Glynn MW, Gorski JL, Seaver LH, Glover TW. 2000. Mutations in FOXC2 (MFH-1), a forkhead family transcription factor, are responsible for the hereditary lymphedema-distichiasis syndrome. Am J Hum Genet 67: 1382-1388.

Ferrell RE, Kimak MA, Lawrence EC, Finegold DN. 2008. Candidate gene analysis in primary lymphedema. Lymphat Res Biol 6: 69-76.

Ferrell RE, Baty CJ, Kimak MA, Karlsson JM, Lawrence EC Franke-Snyder M, Meriney SD, Feingold E, Finegold DN. 2010. GJC2 missense mutations cause human lymphedema. Am J Hum Genet 86: 943-948.

Finegold DN, Kimak MA, Lawrence EC, Levinson KL, Cherniske EM, Pober BR, Dunlap JW, Ferrell RE. 2001. Truncating mutations in FOXC2 cause multiple lymphedema syndromes. Hum Mol Genet 10: 1185-1189.

Finegold DN, Schacht V, Kimak MA, Lawrence EC, Foeldi E, Karlsson JM, Baty CJ, Ferrell RE. 2008. HGF and MET mutations in primary and secondary lymphedema. Lymphat Res Biol 6: 65-68.

Fong GH, Rossant J, Gertsenstein M, Breitman ML. 1995. Role of the Flt-1 receptor tyrosine kinase in regulating the assembly of vascular endothelium. Nature 376: 66-70.

Gale NW, Thurston G, Hackett SF, Renard R, Wang Q, McClain J, Martin C, Witte C, Witte MH, Jackson D, et al. 2002. Angiopoietin-2 is required for postnatal angiogenesis and lymphatic patterning, and only the latter role is rescued by Angiopoietin-1. Dev Cell 3: 411-423.

Gallione CJ, Repetto GM, Legius E, Rustgi AK, Schelley SL, Tejpar S, Mitchell G, Drouin E, Westermann CJ, Marchuk DA. 2004. A combined syndrome of juvenile polyposis and hereditary haemorrhagic telangiectasia associated with mutations in MADH4 (SMAD4). Lancet 363: 852-859.

Ghalamkarpour A, Morlot S, Raas-Rothschild A, Utkus A, Mulliken JB, Boon LM, Vikkula M. 2006. Hereditary lymphedema type I associated with VEGFR3 mutation: The first de novo case and atypical presentations. Clin Genet 70: 330-335.

Ghalamkarpour A, Devriendt K, Vikkula M. 2008. SOX18 and the hypotrichosis-lymphedema-telangiectasia syndrome. In Inborn errors of development, 2nd ed. (ed. Epstein CJ, et al.), pp. 913-915. Oxford University Press, Oxford.

Ghalamkarpour A, Debauche C, Haan E, Van Regemorter N, Sznajer Y, Thomas D, Revencu N, Gillerot Y, Boon LM, Vikkula M. 2009a. Sporadic in utero generalized edema caused by mutations in the lymphangiogenic genes VEGFR3 and FOXC2. J Pediatr 155: 90-93.

Ghalamkarpour A, Holnthoner W, Saharinen P, Boon LM, Mulliken JB, Alitalo K, Vikkula M. 2009b. Recessive primary congenital lymphoedema caused by a VEGFR3 mutation. J Med Genet 46: 399-404.

Glading A, Han J, Stockton RA, Ginsberg MH. 2007. KRIT-1/CCM1 is a Rap1 effector that regulates endothelial cell-cell junctions. J Cell Biol 179: 247-254.

Goodman TF, Abele DC. 1971. Multiple glomus tumors. A clinical and electron microscopic study. Arch Dermatol 103: 11-23.

Gottfried ON, Viskochil DH, Couldwell WT. 2010. Neurofibromatosis Type 1 and tumorigenesis: Molecular mechanisms and therapeutic implications. Neurosurg Focus 28: e8 doi: 10.3171/2009.11.FOCUS09221.

Goumans MJ, Valdimarsdottir G, Itoh S, Rosendahl A, Sideras P, ten Dijke P. 2002. Balancing the activation state of the endothelium via two distinct TGF- $\beta$ type I receptors. EMBO J 21: 1743-1753.

Govani FS, Shovlin CL. 2009. Hereditary haemorrhagic telangiectasia: A clinical and scientific review. Eur $J$ Hum Genet 17: 860-871.

Greinwald JH Jr, Burke DK, Bonthius DJ, Bauman NM, Smith RJ. 1999. An update on the treatment of hemangiomas in children with interferon alfa-2a. Arch Otolaryngol Head Neck Surg 125: 21-27.

Grewal T, Evans R, Rentero C, Tebar F, Cubells L, de Diego I, Kirchhoff MF, Hughes WE, Heeren J, Rye KA, et al. 2005. Annexin A6 stimulates the membrane recruitment of pp120GAP to modulate Ras and Raf-1 activity. Oncogene 24: 5809-5820.

Grisendi S, Chambraud B, Gout I, Comoglio PM, Crepaldi T. 2001. Ligand-regulated binding of FAP68 to the hepatocyte growth factor receptor. J Biol Chem 276: 46632-46638.

Haggstrom AN, Drolet BA, Baselga E, Chamlin SL, Garzon MC, Horii KA, Lucky AW, Mancini AJ, Metry DW, Newell B, et al. 2007. Prospective study of infantile hemangiomas: Demographic, prenatal, and perinatal characteristics. J Pediatr 150: 291-294.

Hammill AM, Wentzel M, Gupta A, Nelson S, Lucky A, Elluru R, Dasgupta R, Azizkhan RG, Adams DM. 2011. Sirolimus for the treatment of complicated vascular anomalies in children. Pediatr Blood Cancer doi: $101002 / \mathrm{pbc} 23124$.

Hansen TM, Singh H, Tahir TA, Brindle NP. 2010. Effects of angiopoietins- 1 and -2 on the receptor tyrosine kinase Tie 2 are differentially regulated at the endothelial cell surface. Cell Signal 22: 527-532.

Harfouche R, Gratton JP, Yancopoulos GD, Noseda M, Karsan A, Hussain SN. 2003. Angiopoietin-1 activates both anti- and proapoptotic mitogen-activated protein kinases. FASEB J 17: 1523-1525.

Hayashi H, Kume T. 2008. Foxc transcription factors directly regulate Dll4 and Hey2 expression by interacting with the VEGF-Notch signaling pathways in endothelial cells. PLoS One 3: e2401. doi: 10.1371/journal.pone.0002401.

Hayashi H, Sano H, Seo S, Kume T. 2008. The Foxc2 transcription factor regulates angiogenesis via induction of integrin $\beta 3$ expression. J Biol Chem 283: 23791-23800.

Henkemeyer M, Rossi DJ, Holmyard DP, Puri MC, Mbamalu G, Harpal K, Shih TS, Jacks T, Pawson T. 1995. Vascular system defects and neuronal apoptosis in mice 
M. Uebelhoer et al.

lacking ras GTPase-activating protein. Nature 377: 695-701.

Hershkovitz D, Bergman R, Sprecher E. 2008. A novel mutation in RASA1 causes capillary malformation and limb enlargement. Arch Dermatol Res 300: 385-388.

Hogan BM, Bussmann J, Wolburg H, Schulte-Merker S. 2008. ccm1 cell autonomously regulates endothelial cellular morphogenesis and vascular tubulogenesis in zebrafish. Hum Mol Genet 17: 2424-2432.

Holland KE, Frieden IJ, Frommelt PC, Mancini AJ, Wyatt D, Drolet BA. 2010. Hypoglycemia in children taking propranolol for the treatment of infantile hemangioma. Arch Dermatol 146: 775-778.

Hu HT, Huang YH, Chang YA, Lee CK, Jiang MJ, Wu LW. 2008. Tie2-R849W mutant in venous malformations chronically activates a functional STAT1 to modulate gene expression. J Invest Dermatol 128: 2325-2333.

Irrthum A, Karkkainen MJ, Devriendt K, Alitalo K, Vikkula M. 2000. Congenital hereditary lymphedema caused by a mutation that inactivates VEGFR3 tyrosine kinase. Am J Hum Genet 67: 295-301.

Irrthum A, Devriendt K, Chitayat D, Matthijs G, Glade C, Steijlen PM, Fryns JP, Van Steensel MA, Vikkula M. 2003. Mutations in the transcription factor gene SOX 18 underlie recessive and dominant forms of hypotrichosis-lymphedema-telangiectasia. Am J Hum Genet 72: 1470-1478.

Jacobs AH, Walton RG. 1976. The incidence of birthmarks in the neonate. Pediatrics 58: 218-222.

Jinnin M, Medici D, Park L, Limaye N, Liu Y, Boscolo E, Bischoff J, Vikkula M, Boye E, Olsen BR. 2008. Suppressed NFAT-dependent VEGFR1 expression and constitutive VEGFR2 signaling in infantile hemangioma. Nat Med 14: $1236-1246$.

Johannessen CM, Reczek EE, James MF, Brems H, Legius E, Cichowski K. 2005. The NF1 tumor suppressor critically regulates TSC2 and mTOR. Proc Natl Acad Sci 102: 8573-8578.

Johnson DW, Berg JN, Baldwin MA, Gallione CJ, Marondel I, Yoon SJ, Stenzel TT, Speer M, Pericak-Vance MA, Diamond A, et al. 1996. Mutations in the activin receptor-like kinase 1 gene in hereditary haemorrhagic telangiectasia type 2. Nat Genet 13: 189-195.

Karkkainen MJ, Ferrell RE, Lawrence EC, Kimak MA, Levinson KL, McTigue MA, Alitalo K, Finegold DN. 2000 Missense mutations interfere with VEGFR-3 signalling in primary lymphoedema. Nat Genet 25: 153-159.

Karkkainen MJ, Saaristo A, Jussila L, Karila KA, Lawrence EC, Pajusola K, Bueler H, Eichmann A, Kauppinen R, Kettunen MI, et al. 2001. A model for gene therapy of human hereditary lymphedema. Proc Natl Acad Sci 98: 12677-12682.

Karnezis TT, Davidson TM. 2011. Efficacy of intranasal bevacizumab (Avastin) treatment in patients with hereditary hemorrhagic telangiectasia-associated epistaxis. Laryngoscope 121: 636-638.

Karpanen T, Wirzenius M, Makinen T, Veikkola T, Haisma HJ, Achen MG, Stacker SA, Pytowski B, Yla-Herttuala S, Alitalo K. 2006. Lymphangiogenic growth factor responsiveness is modulated by postnatal lymphatic vessel maturation. Am J Pathol 169: 708-718.
Khan ZA, Boscolo E, Picard A, Psutka S, Melero-Martin JM, Bartch TC, Mulliken JB, Bischoff J. 2008. Multipotential stem cells recapitulate human infantile hemangioma in immunodeficient mice. J Clin Invest 118: 2592-2599.

Kidoya H, Ueno M, Yamada Y, Mochizuki N, Nakata M, Yano T, Fujii R, Takakura N. 2008. Spatial and temporal role of the apelin/APJ system in the caliber size regulation of blood vessels during angiogenesis. EMBO J 27: 522-534.

Kobayashi H, DeBusk LM, Babichev YO, Dumont DJ, Lin PC. 2006. Hepatocyte growth factor mediates angiopoietin-induced smooth muscle cell recruitment. Blood 108: $1260-1266$.

Kontos CD, Stauffer TP, Yang WP, York JD, Huang L, Blanar MA, Meyer T, Peters KG. 1998. Tyrosine 1101 of Tie2 is the major site of association of pp85 and is required for activation of phosphatidylinositol 3-kinase and Akt. Mol Cell Biol 18: 4131-4140.

Korpelainen EI, Karkkainen M, Gunji Y, Vikkula M, Alitalo K. 1999. Endothelial receptor tyrosine kinases activate the STAT signaling pathway: Mutant Tie-2 causing venous malformations signals a distinct STAT activation response. Oncogene 18: 1-8.

Kriederman BM, Myloyde TL, Witte MH, Dagenais SL, Witte CL, Rennels M, Bernas MJ, Lynch MT, Erickson RP, Caulder MS, et al. 2003. FOXC2 haploinsufficient mice are a model for human autosomal dominant lymphedema-distichiasis syndrome. Hum Mol Genet 12: 1179-1185.

Kulkarni SV, Gish G, van der Geer P, Henkemeyer M, Pawson T. 2000. Role of p120 Ras-GAP in directed cell movement. J Cell Biol 149: 457-470.

Laberge-le Couteulx S, Jung HH, Labauge P, Houtteville JP, Lescoat C, Cecillon M, Marechal E, Joutel A, Bach JF Tournier-Lasserve E. 1999. Truncating mutations in CCM1, encoding KRIT1, cause hereditary cavernous angiomas. Nat Genet 23: 189-193.

Leaute-Labreze C, Dumas de la Roque E, Hubiche T, Boralevi F, Thambo JB, Taieb A. 2008. Propranolol for severe hemangiomas of infancy. N Engl J Med 358: 2649-2651.

Lebrin F, Goumans MJ, Jonker L, Carvalho RL, Valdimarsdottir G, Thorikay M, Mummery C, Arthur HM, ten Dijke P. 2004. Endoglin promotes endothelial cell proliferation and TGF- $\beta$ /ALK1 signal transduction. EMBO J 23: 4018-4028.

Lebrin F, Srun S, Raymond K, Martin S, van den Brink S, Freitas C, Breant C, Mathivet T, Larrivee B, Thomas JL, et al. 2010. Thalidomide stimulates vessel maturation and reduces epistaxis in individuals with hereditary hemorrhagic telangiectasia. Nat Med 16: 420-428.

Limaye N, Wouters V, Uebelhoer M, Tuominen M, Wirkkala R, Mulliken JB, Eklund L, Boon LM, Vikkula M. 2009. Somatic mutations in angiopoietin receptor gene TEK cause solitary and multiple sporadic venous malformations. Nat Genet 41: 118-124.

Liquori CL, Berg MJ, Siegel AM, Huang E, Zawistowski JS, Stoffer T, Verlaan D, Balogun F, Hughes L, Leedom TP, et al. 2003. Mutations in a gene encoding a novel protein containing a phosphotyrosine-binding domain cause type 2 cerebral cavernous malformations. Am J Hum Genet 73: 1459-1464. 
Liquori CL, Berg MJ, Squitieri F, Ottenbacher M, Sorlie M, Leedom TP, Cannella M, Maglione V, Ptacek L, Johnson EW, et al. 2006. Low frequency of PDCD10 mutations in a panel of CCM3 probands: Potential for a fourth CCM locus. Hum Mutat 27: 118.

Liu Y, Fang Y, Dong P, Gao J, Liu R, Hhahbaz M, Bi Y, Ding Z, Tian H, Liu Z. 2008. Effect of vascular endothelial growth factor C (VEGF-C) gene transfer in rat model of secondary lymphedema. Vascul Pharmacol 48: 150-156.

Mahmoud M, Allinson KR, Zhai Z, Oakenfull R, Ghandi P, Adams RH, Fruttiger M, Arthur HM. 2010. Pathogenesis of arteriovenous malformations in the absence of endoglin. Circ Res 106: 1425-1433

Maisonpierre PC, Suri C, Jones PF, Bartunkova S, Wiegand SJ, Radziejewski C, Compton D, McClain J, Aldrich TH, Papadopoulos N, et al. 1997. Angiopoietin-2, a natural antagonist for Tie2 that disrupts in vivo angiogenesis. Science 277: 55-60.

Makinen T, Jussila L, Veikkola T, Karpanen T, Kettunen MI, Pulkkanen KJ, Kauppinen R, Jackson DG, Kubo H, Nishikawa S, et al. 2001. Inhibition of lymphangiogenesis with resulting lymphedema in transgenic mice expressing soluble VEGF receptor-3. Nat Med 7: 199-205.

Malik S, Grzeschik KH. 2008. Congenital, low penetrance lymphedema of lower limbs maps to chromosome 6q16.2-q22.1 in an inbred Pakistani family. Hum Genet 123: $197-205$

McAllister KA, Grogg KM, Johnson DW, Gallione CJ, Baldwin MA, Jackson CE, Helmbold EA, Markel DS, McKinnon WC, Murrell J, et al. 1994. Endoglin, a TGF- $\beta$ binding protein of endothelial cells, is the gene for hereditary haemorrhagic telangiectasia type 1. Nat Genet 8: $345-351$.

McIntyre BA, Brouillard P, Aerts V, Gutierrez-Roelens I, Vikkula M. 2004. Glomulin is predominantly expressed in vascular smooth muscle cells in the embryonic and adult mouse. Gene Expr Patterns 4: 351-358.

Mori Y, Sahara H, Matsumoto K, Takahashi N, Yamazaki T, Ohta K, Aoki S, Miura M, Sugawara F, Sakaguchi K, et al. 2008. Downregulation of Tie2 gene by a novel antitumor sulfolipid, $3^{\prime}$-sulfoquinovosyl-1'-monoacylglycerol, targeting angiogenesis. Cancer Sci 99: 1063-1070.

Morris PN, Dunmore BJ, Tadros A, Marchuk DA, Darland DC, D'Amore PA, Brindle NP. 2005. Functional analysis of a mutant form of the receptor tyrosine kinase Tie2 causing venous malformations. J Mol Med 83: 58-63.

Mosca L, Grady D, Barrett-Connor E, Collins P, Wenger N, Abramson BL, Paganini-Hill A, Geiger MJ, Dowsett SA, Amewou-Atisso M, et al. 2009. Effect of raloxifene on stroke and venous thromboembolism according to subgroups in postmenopausal women at increased risk of coronary heart disease. Stroke 40: 147-155.

Mulliken JB, Glowacki J. 1982. Hemangiomas and vascular malformations in infants and children: A classification based on endothelial characteristics. Plast Reconstr Surg 69: $412-422$.

Nobuhara Y, Onoda N, Fukai K, Hosomi N, Ishii M, Wakasa K, Nishihara T, Ishikawa T, Hirakawa K. 2006. TIE2 gain-of-function mutation in a patient with pancreatic lymphangioma associated with blue rubber-bleb nevus syndrome: Report of a case. Surg Today 36: 283-286.
Oh SP, Seki T, Goss KA, Imamura T, Yi Y, Donahoe PK, Li L, Miyazono K, ten Dijke P, Kim S, et al. 2000. Activin receptor-like kinase 1 modulates transforming growth factor- $\beta 1$ signaling in the regulation of angiogenesis. Proc Natl Acad Sci 97: 2626-2631.

O’Hagan AH, Moloney FJ, Buckley C, Bingham EA, Walsh MY, McKenna KE, McGibbon D, Hughes AE. 2006. Mutation analysis in Irish families with glomuvenous malformations. Br J Dermatol 154: 450-452.

Olson MF. 2008. Applications for ROCK kinase inhibition. Curr Opin Cell Biol 20: 242-248.

Park SO, Lee YJ, Seki T, Hong KH, Fliess N, Jiang Z, Park A, Wu X, Kaartinen V, Roman BL, et al. 2008. ALK5- and TGFBR2-independent role of ALK1 in the pathogenesis of hereditary hemorrhagic telangiectasia type 2 . Blood 111: $633-642$

Park SO, Wankhede M, Lee YJ, Choi EJ, Fliess N, Choe SW, Oh SH, Walter G, Raizada MK, Sorg BS, et al. 2009. Realtime imaging of de novo arteriovenous malformation in a mouse model of hereditary hemorrhagic telangiectasia. J Clin Invest 119: 3487-3496.

Pennisi D, Bowles J, Nagy A, Muscat G, Koopman P. 2000a. Mice null for sox 18 are viable and display a mild coat defect. Mol Cell Biol 20: 9331-9336.

Pennisi D, Gardner J, Chambers D, Hosking B, Peters J, Muscat G, Abbott C, Koopman P. 2000b. Mutations in Sox18 underlie cardiovascular and hair follicle defects in ragged mice. Nat Genet 24: 434-437.

Petrova TV, Karpanen T, Norrmen C, Mellor R, Tamakoshi T, Finegold D, Ferrell R, Kerjaschki D, Mortimer P, YlaHerttuala S, et al. 2004. Defective valves and abnormal mural cell recruitment underlie lymphatic vascular failure in lymphedema distichiasis. Nat Med 10: 974-981.

Plummer NW, Gallione CJ, Srinivasan S, Zawistowski JS, Louis DN, Marchuk DA. 2004. Loss of p53 sensitizes mice with a mutation in Ccm1 (KRIT1) to development of cerebral vascular malformations. Am J Pathol 165: 1509-1518.

Plummer NW, Squire TL, Srinivasan S, Huang E, Zawistowski JS, Matsunami H, Hale LP, Marchuk DA. 2006. Neuronal expression of the $\mathrm{Ccm} 2$ gene in a new mouse model of cerebral cavernous malformations. Mamm Genome 17: $119-128$.

Revencu N, Vikkula M. 2006. Cerebral cavernous malformation: New molecular and clinical insights. J Med Genet 43 716-721.

Revencu N, Boon LM, Mulliken JB, Enjolras O, Cordisco MR, Burrows PE, Clapuyt P, Hammer F, Dubois J, Baselga E, et al. 2008a. Parkes Weber syndrome, vein of Galen aneurysmal malformation, and other fast-flow vascular anomalies are caused by RASA1 mutations. Hum Mutat 29: 959-965.

Revencu N, Boon LM, Mulliken JB, Vikkula M. 2008b. RASA1 capillary malformation-arteriovenous malformation. In Inborn errors of development, 2nd ed. (ed. Epstein CJ, et al.), pp. 647-650. Oxford University Press, Oxford.

Riant F, Bergametti F, Ayrignac X, Boulday G, TournierLasserve E. 2010. Recent insights into cerebral cavernous malformations: The molecular genetics of CCM. FEBS J 277: $1070-1075$. 
M. Uebelhoer et al.

Rigamonti D, Hadley MN, Drayer BP, Johnson PC, Hoenig-Rigamonti K, Knight JT, Spetzler RF. 1988. Cerebral cavernous malformations. Incidence and familial occurrence. N Engl J Med 319: 343-347.

Rockson SG. 2008. Diagnosis and management of lymphatic vascular disease. J Am Coll Cardiol 52: 799-806.

Sato TN, Tozawa Y, Deutsch U, Wolburg-Buchholz K, Fujiwara Y, Gendron-Maguire M, Gridley T, Wolburg H, Risau W, Qin Y. 1995. Distinct roles of the receptor tyrosine kinases Tie-1 and Tie-2 in blood vessel formation. Nature 376: 70-74.

Seegar TC, Eller B, Tzvetkova-Robev D, Kolev MV, Henderson SC, Nikolov DB, Barton WA. 2010. Tie1-Tie2 interactions mediate functional differences between angiopoietin ligands. Mol Cell 37: 643-655.

Seki T, Hong KH, Oh SP. 2006. Nonoverlapping expression patterns of ALK1 and ALK5 reveal distinct roles of each receptor in vascular development. Lab Invest 86: $116-$ 129.

Semones M, Feng Y, Johnson N, Adams JL, Winkler J, Hansbury M. 2007. Pyridinylimidazole inhibitors of Tie2 kinase. Bioorg Med Chem Lett 17: 4756-4760.

Serebriiskii I, Estojak J, Sonoda G, Testa JR, Golemis EA. 1997. Association of Krev-1/rapla with Kritl, a novel ankyrin repeat-containing protein encoded by a gene mapping to 7q21-22. Oncogene 15: 1043-1049.

Shalaby F, Rossant J, Yamaguchi TP, Gertsenstein M, Wu XF, Breitman ML, Schuh AC. 1995. Failure of blood-island formation and vasculogenesis in Flk-1-deficient mice. Nature 376: 62-66.

Shao ES, Lin L, Yao Y, Bostrom KI. 2009. Expression of vascular endothelial growth factor is coordinately regulated by the activin-like kinase receptors 1 and 5 in endothelial cells. Blood 114: 2197-2206.

Sirard C, de la Pompa JL, Elia A, Itie A, Mirtsos C, Cheung A, Hahn S, Wakeham A, Schwartz L, Kern SE, et al. 1998. The tumor suppressor gene Smad4/Dpc4 is required for gastrulation and later for anterior development of the mouse embryo. Genes Dev 12: 107-119.

Srinivasan S, Hanes MA, Dickens T, Porteous ME, Oh SP, Hale LP, Marchuk DA. 2003. A mouse model for hereditary hemorrhagic telangiectasia (HHT) type 2. Hum Mol Genet 12: 473-482.

Stockton RA, Shenkar R, Awad IA, Ginsberg MH. 2010. Cerebral cavernous malformations proteins inhibit Rho kinase to stabilize vascular integrity. $J$ Exp Med 207: 881-896.

Suri C, Jones PF, Patan S, Bartunkova S, Maisonpierre PC Davis S, Sato TN, Yancopoulos GD. 1996. Requisite role of angiopoietin-1, a ligand for the TIE2 receptor, during embryonic angiogenesis. Cell 87: 1171-1180.

Suri C, McClain J, Thurston G, McDonald DM, Zhou H, Oldmixon EH, Sato TN, Yancopoulos GD. 1998. Increased vascularization in mice overexpressing angiopoietin-1. Science 282: 468-471.

Szuba A, Skobe M, Karkkainen MJ, Shin WS, Beynet DP, Rockson NB, Dakhil N, Spilman S, Goris ML, Strauss HW, et al. 2002. Therapeutic lymphangiogenesis with human recombinant VEGF-C. FASEB J 16: 1985-1987.

Taher TE, Derksen PW, de Boer OJ, Spaargaren M, Teeling P, van der Wal AC, Pals ST. 2002. Hepatocyte growth factor triggers signaling cascades mediating vascular smooth muscle cell migration. Biochem Biophys Res Commun 298: $80-86$.

Takahashi K, Mulliken JB, Kozakewich HP, Rogers RA, Folkman J, Ezekowitz RA. 1994. Cellular markers that distinguish the phases of hemangioma during infancy and childhood. J Clin Invest 93: 2357-2364.

Tammela T, Saaristo A, Holopainen T, Lyytikka J, Kotronen A, Pitkonen M, Abo-Ramadan U, Yla-Herttuala S, Petrova TV, Alitalo K. 2007. Therapeutic differentiation and maturation of lymphatic vessels after lymph node dissection and transplantation. Nat Med 13: 1458-1466.

Therapontos C, Erskine L, Gardner ER, Figg WD, Vargesson N. 2009. Thalidomide induces limb defects by preventing angiogenic outgrowth during early limb formation. Proc Natl Acad Sci 106: 8573-8578.

Thomas G, Hall MN. 1997. TOR signalling and control of cell growth. Curr Opin Cell Biol 9: 782-787.

Uhlik MT, Abell AN, Johnson NL, Sun W, Cuevas BD, LobelRice KE, Horne EA, Dell'Acqua ML, Johnson GL. 2003. Rac-MEKK3-MKK3 scaffolding for p38 MAPK activation during hyperosmotic shock. Nat Cell Biol 5: 1104-1110.

Valenzuela DM, Griffiths JA, Rojas J, Aldrich TH, Jones PF, Zhou H, McClain J, Copeland NG, Gilbert DJ, Jenkins NA, et al. 1999. Angiopoietins 3 and 4: Diverging gene counterparts in mice and humans. Proc Natl Acad Sci 96: $1904-1909$.

Vikkula M, Boon LM, Carraway KL III, Calvert JT, Diamonti AJ, Goumnerov B, Pasyk KA, Marchuk DA, Warman ML Cantley LC, et al. 1996. Vascular dysmorphogenesis caused by an activating mutation in the receptor tyrosine kinase TIE2. Cell 87: 1181-1190.

Vlahovic A, Simic R, Djokic D, Ceran C. 2009. Diffuse neonatal hemangiomatosis treatment with cyclophosphamide: A case report. J Pediatr Hematol Oncol 31: $858-860$.

Voss K, Stahl S, Schleider E, Ullrich S, Nickel J, Mueller TD, Felbor U. 2007. CCM3 interacts with CCM2 indicating common pathogenesis for cerebral cavernous malformations. Neurogenetics 8: $249-256$.

Voss K, Stahl S, Hogan BM, Reinders J, Schleider E, SchulteMerker S, Felbor U. 2009. Functional analyses of human and zebrafish 18-amino acid in-frame deletion pave the way for domain mapping of the cerebral cavernous malformation 3 protein. Hum Mutat 30: 1003-1011.

Walter JW, Blei F, Anderson JL, Orlow SJ, Speer MC, Marchuk DA. 1999. Genetic mapping of a novel familial form of infantile hemangioma. Am J Med Genet 82: $77-83$.

Whimster IW. 1976. The pathology of lymphangioma circumscriptum. Br J Dermatol 94: 473-486.

Whitehead KJ, Plummer NW, Adams JA, Marchuk DA, Li DY. 2004. Ccml is required for arterial morphogenesis: Implications for the etiology of human cavernous malformations. Development 131: 1437-1448.

Whitehead KJ, Chan AC, Navankasattusas S, Koh W, London NR, Ling J, Mayo AH, Drakos SG, Jones CA, Zhu W, et al. 2009. The cerebral cavernous malformation signaling pathway promotes vascular integrity via Rho GTPases. Nat Med 15: 177-184. 
Winnier GE, Hargett L, Hogan BL. 1997. The winged helix transcription factor MFH1 is required for proliferation and patterning of paraxial mesoderm in the mouse embryo. Genes Dev 11: 926-940.

Wouters V, Limaye N, Uebelhoer M, Irrthum A, Boon LM, Mulliken JB, Enjolras O, Baselga E, Berg J, Dompmartin A, et al. 2010. Hereditary cutaneomucosal venous malformations are caused by TIE2 mutations with widely variable hyper-phosphorylating effects. Eur J Hum Genet 18: 414-420.

Wustehube J, Bartol A, Liebler SS, Brutsch R, Zhu Y, Felbor U, Sure U, Augustin HG, Fischer A. 2010. Cerebral cavernous malformation protein CCM1 inhibits sprouting angiogenesis by activating DELTA-NOTCH signaling. Proc Natl Acad Sci 107: 12640-12645.

Xue Y, Cao R, Nilsson D, Chen S, Westergren R, Hedlund EM, Martijn C, Rondahl L, Krauli P, Walum E, et al. 2008. FOXC2 controls Ang-2 expression and modulates angiogenesis, vascular patterning, remodeling, and functions in adipose tissue. Proc Natl Acad Sci 105: 10167-10172.

Yang XY, Guan M, Vigil D, Der CJ, Lowy DR, Popescu NC. 2009. p120Ras-GAP binds the DLC1 Rho-GAP tumor suppressor protein and inhibits its RhoA GTPase and growth-suppressing activities. Oncogene 28: 1401-1409.

Yuan HT, Khankin EV, Karumanchi SA, Parikh SM. 2009. Angiopoietin 2 is a partial agonist/antagonist of Tie2 signaling in the endothelium. Mol Cell Biol 29: 2011-2022.

Yue Y, Lypowy J, Hedhli N, Abdellatif M. 2004. Ras GTPase-activating protein binds to Akt and is required for its activation. J Biol Chem 279: 12883-12889.

Zawistowski JS, Stalheim L, Uhlik MT, Abell AN, Ancrile BB, Johnson GL, Marchuk DA. 2005. CCM1 and CCM2 protein interactions in cell signaling: Implications for cerebral cavernous malformations pathogenesis. Hum Mol Genet 14: 2521-2531.

Zhang J, Clatterbuck RE, Rigamonti D, Chang DD, Dietz HC. 2001. Interaction between kritl and icap $1 \alpha$ infers perturbation of integrin $\beta 1$-mediated angiogenesis in the pathogenesis of cerebral cavernous malformation. Hum Mol Genet 10: 2953-2960.

Zhang L, Lin X, Wang W, Zhuang X, Dong J, Qi Z, Hu Q. 2005. Circulating level of vascular endothelial growth factor in differentiating hemangioma from vascular malformation patients. Plast Reconstr Surg 116: 200-204. 


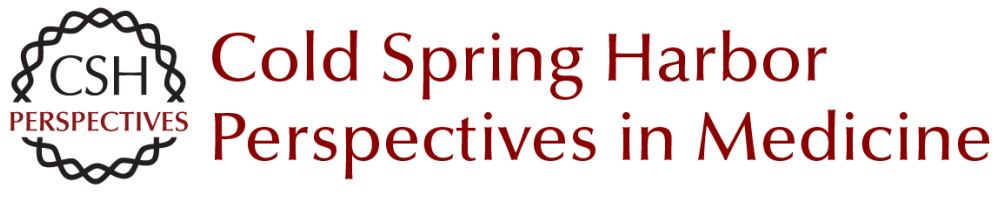

\title{
Vascular Anomalies: From Genetics toward Models for Therapeutic Trials
}

\author{
Melanie Uebelhoer, Laurence M. Boon and Miikka Vikkula
}

Cold Spring Harb Perspect Med 2012; doi: 10.1101/cshperspect.a009688 originally published online March 13, 2012

\section{Subject Collection Angiogenesis}

\section{Extracellular Matrix Regulation of Vascular}

Morphogenesis, Maturation, and Stabilization George E. Davis and Scott S. Kemp

Endothelial Cell-Pericyte Interactions in the

Pathogenesis of Cerebral Cavernous

Malformations (CCMs)

Wang Min and Jenny Huanjiao Zhou

Lymphatic Clearance and Pump Function Jerome W. Breslin

Platelets and (Lymph)angiogenesis Harvey G. Roweth and Elisabeth M. Battinelli

Modeling Brain Vasculature Immune Interactions In Vitro

Ruth Lyck, Hideaki Nishihara, Sidar Aydin, et al.

Human Endothelial Colony-Forming Cells Juan M. Melero-Martin

The Beauty and Complexity of Blood Vessel Patterning

Victoria L. Bautch and Yoh-suke Mukouyama

Endothelialitis, Microischemia, and

Intussusceptive Angiogenesis in COVID-19

Steven J. Mentzer, Maximilian Ackermann and

Danny Jonigk
Regulation of the Blood-Brain Barrier in Health and Disease

Cara C. Rada, Kanako Yuki, Jie Ding, et al.

Targeting Angiogenesis via Resolution of Inflammation

Abigail G. Kelly and Dipak Panigrahy

Notch Signaling in the Vasculature: Angiogenesis and Angiocrine Functions

Sana S. Hasan and Andreas Fischer

Signal Transduction and Gene Regulation in the

Endothelium

Michel V. Levesque and Timothy Hla

Buttons and Zippers: Endothelial Junctions in

Lymphatic Vessels

Peter Baluk and Donald M. McDonald

Endothelial Cell Fate Determination: A Top Notch Job in Vascular Decision-Making

L.A. Naiche, Stephanie R. Villa and Jan K. Kitajewski

Leukocyte Trafficking in Lymphatic Vessels Aline Bauer, Hazal Tatliadim and Cornelia Halin

Lymphatic Tissue and Organ Engineering for In Vitro Modeling and In Vivo Regeneration Anna M. Kolarzyk, Gigi Wong and Esak Lee

For additional articles in this collection, see http://perspectivesinmedicine.cshlp.org/cgi/collection/ 